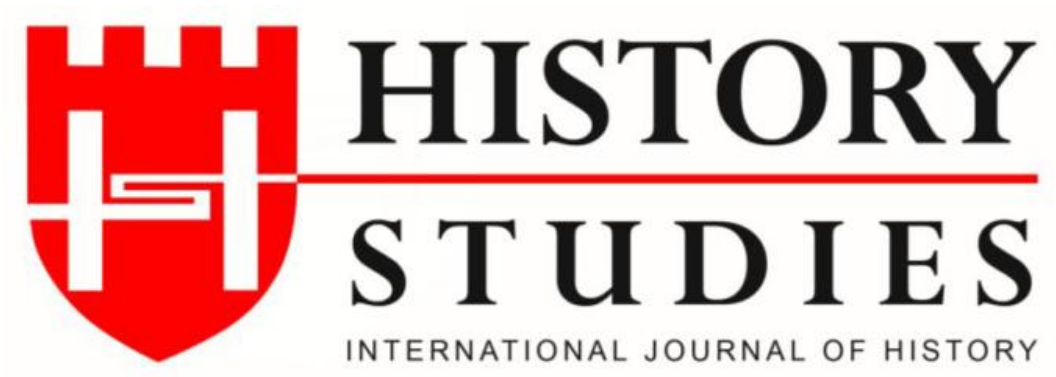

ISSN: 13094173 (Online) 1309 - 4688 (Print)

Volume 12 Issue 5, October 2020

DOI Number: 10.9737/hist.2020.943

Araştırma Makalesi

Makalenin Geliş Tarihi: 09.07.2020 Kabul Tarihi: 18.08.2020

Atıf Künyesi: İsrafil Karataş, "1971 Bingöl Depremi”, History Studies, 12/5, Ekim 2020, s. 2797-2820.

\title{
1971 Bingöl Depremi
}

1971 Bingöl Earthquake

\section{Dr. İsrafil Karataş}

ORCID No: 0000-0003-4940-9344

Alanya Alaaddin Keykubat Üniversitesi

\section{$\ddot{\mathbf{O} z}$}

Dünyanın en etkin deprem kuşaklarından biri üzerinde bulunan Türkiye'de geçmişte çok büyük depremler meydana gelmiştir. Bunlardan birisi de birinci derece deprem bölgesinde bulunan Bingöl'deki 22 Mayıs 1971 tarihli depremdir. 6.8 büyüklüğündeki bu deprem sonucunda çok sayıda insan hayatını kaybettiği gibi Bingöl de büyük bir tahribata uğramıştır. Türkiye'nin 12 Mart Muhtırası nedeniyle içinde bulunduğu krize ilave olarak bir de bu felaketin ortaya çıkması, ayrıca 12 Mayıs 1971 tarihinde de Burdur Depremi’nin meydan gelmiş olması Türkiye'yi zor durumda bırakmıştır. Bu çalışmanın amacı, 1971 Bingöl Depremi'ni tarihsel açıdan incelemenin yanı sıra böyle bir felaket karşısında Türkiye'nin nasıl bir afet yönetimi uyguladığını ve ne oranda başarılı olduğunu ortaya koymaktır. Çalışmada yerel ve ulusal basın, Cumhurbaşkanlığı Cevdet Sunay ve Cumhurbaşkanlığı Devlet Arşivleri Başkanlığı Cumhuriyet Arşivi belgeleri, Millet Meclisi ve Cumhuriyet Senatosu tutanak dergileri, resmi yayınlar ve telif eserler kullanılmıştır.

Anahtar Kelimeler: Deprem, Bingöl, 22 Mayıs 1971, Afet Yönetimi.

\begin{abstract}
Many large earthquakes occurred in the past in Turkey which is located on one of the world's most influential earthquake zones. One of them is the earthquake dated May 22, 1971 in Bingöl which is located in the first degree earthquake zone. As a result of this 6.8 magnitude earthquake, many people lost their lives and Bingöl also suffered a great destruction. This disaster occurred in addition to the crisis happened due to the March 12 Memorandum, also the emergence of earthquake in Burdur in May 12, 1971 left Turkey in a difficult situation. The purpose of this study is to investigate 1971 Bingöl earthquake from a historical perspective and to reveal how Turkey implements a disaster management for it and to show how successful it is. In this study, local and national press, Presidential Cevdet Sunay and Republic Archive Documents of the Presidential State Archives, National Assembly and Republic Senate minutes journals, official publications and copyrighted works were used.
\end{abstract}

Keywords: Earthquake, Bingöl, 22 May 1971, Disaster Management. 


\section{Giriş}

Yer kabuğunda fay düzlemi boyunca kırılmaya bağlı olarak ani yer değiştirme sonucu ortaya çıkan dalgaların geçtikleri ortamı ve yer yüzeyini sarsma olayına deprem denir. ${ }^{1}$ Türkiye bulunduğu coğrafya itibariyle en canlı deprem kuşaklarından birisi olan Akdeniz-Alp-Himalaya kuşağı üzerinde yer almaktadır. Bu kuşakta, dünyadaki depremlerin yaklaşık \% 20'si meydana gelmektedir. Söz konusu kuşak Türkiye'de her yıl büyüklüğü 5.0 ila 6.0 arasında değişen en az bir deprem üretmektedir. ${ }^{2}$ Buradan anlaşılacağı üzere, deprem yönünden riskli bir coğrafyada yer alan Türkiye, 1900'den günümüze kadar dünyada meydana gelen büyük depremler açısından 77 deprem ile dördüncü sırada bulunmaktadır. ${ }^{3}$

Kuzey Anadolu ile Doğu Anadolu Fay Hatlarının kesişim noktasında yer alan Bingöl ise birinci derece deprem bölgesi üzerinde bulunmaktadır. ${ }^{4}$ Tarihsel (M.S. 11-1900) ve aletsel dönemlerde (1900-) Bingöl ve çevresinde çok sayıda deprem kaydedilmiştir. ${ }^{5}$ Bingöl'de 1900 ve sonrasında meydana gelen depremler içerisinde en çok can kaybının yaşandığı deprem, 22 Mayıs 1971 tarihli depremdir. Bu depremde 878 kişi hayatını kaybetmiştir. Merkez üssünün Bingöl olduğu diğer büyük depremlere bakılacak olunursa 15 Aralık 1934'te 12, 17 Ağustos 1949'da 450, 4 Şubat 1950'de 20, 24 Eylül 1968'de 2 ve 1 Mayıs 2003'te 184 kişi hayatını kaybetmiştir. ${ }^{6}$ Dolayısıyla 1971 yılındaki deprem kaybedilen insan sayısı açısından diğer depremlerden ayrilmaktadir.

1971 Bingöl Depremi’ni diğer depremlerden ayıran diğer bir özellik ise, depremin meydana geldiği tarihlerde Türkiye'nin içinde bulunduğu siyasi ve sosyo-ekonomik kriz ortamıdır. 12 Mart 1971 Muhtırası'nı müteakip ${ }^{7}$ meşru hükümet olan Süleyman Demirel Hükümeti istifa ederken ${ }^{8}$ yerine Nihat Erim Hükümeti kurduruldu. ${ }^{9}$ Erim Hükümeti'nin kurulmasından sonra da ülkedeki anarşi ortamında bir değişim olmadı. ${ }^{10}$ En son 17 Mayıs 1971 tarihinde İsrail'in İstanbul Başkonsolosu Efraim Elrom, Türkiye Halk Kurtuluş Partisi Cephesi (THKP-C) üyeleri tarafından kaçırıld1 ${ }^{11}$ ve 22 Mayıs'ta öldürüldü. ${ }^{12}$ Türkiye'yi uluslararası alanda zor duruma sokan bu olayın yaşandığ 1 gün Bingöl'de yıkıcı bir depremin meydana gelmesiyle ${ }^{13}$ Türkiye ikinci bir şoku yaşamıştır. Böyle bir siyasi krizin göbeğinde Bingöl'de meydana gelen deprem daha da zor günleri beraberinde getirmiştir. Bunun yanı sıra 10 gün önce vuku bulmuş Burdur

\footnotetext{
${ }^{1}$ Sakir Şahin, “Türkiye'de Afet Yönetimi ve 2023 Hedefleri”, Türk Deprem Araştırmaları Dergisi, Y.2019, C.1, S.2, s. 183.

${ }^{2}$ Türkiye’de Afet Yönetimi ve Doğal Kaynaklı Afet İstatistikleri, Hazırlama Ekibi: Hakan Benli vd., AFAD Yayınları, Ankara 2018, s. 42.

${ }^{3}$ Age, s. 8.

${ }^{4}$ Lütfi İhsan Sezer, "Karlıva (Bingöl) Yöresinin Depremselliği”, Ege Coğrafyası Dergisi, Y.2008, C.17, Sayı:1-2, s. 36; İnci Kuşoğlu, Türkiye'de Orta Büyüklükteki Bazı Depremlerin Artçı Sarsıntı Süreç Analizi, (Kocaeli Üniversitesi Fen Bilimleri Enstitüsü, Yayımlanmamış, Yüksek Lisans Tezi), Kocaeli 2019, s. 42.

${ }^{5}$ Sezer, agm, s. 37-38. Depremlerin şiddetinin aletlerle ölçülmeye başlandığ 1900 ve sonrası döneme aletsel dönem denilmektedir. Mehmet Temizer, 2003 Bingöl Depremi Sonrası Bingöl İlinin Hasar Durumlarının Analizi, (Fırat Üniversitesi Fen Bilimleri Enstitüsü, Yayımlanmamış Yüksek Lisans Tezi), Elazığ 2013, s. 20.

${ }^{6}$ TMMOB Makine Mühendisleri Odasl, Türkiye'de Deprem Gerçeği ve TMMOB Makine Makine Mühendisleri Odasının Önerileri (Oda Raporu), Yayınevi ve yeri yok, 2010, s. 3-7; Temizer, agt, s. 20-21.

7 “Komutanlar Ültimatom Verdi”, Son Havadis, 13 Mart 1971.

8 "Demirel Hükümeti Çekildi", Tercüman, 13 Mart 1971.

9 "Yeni kabine işbaşı yaptı", Hürriyet, 27 Mart 1971.

${ }^{10}$ Nihat Erim, 12 Mart Anılarl, Yapı Kredi Yayınları, İstanbul 2007, s. 217-218.

11 “İstanbul'daki İsrail Konsolosu kaçırıldı", Akşam, 18 Mayıs 1971.

12 "İsrail Başkonsolosu hunharca öldürüldü”, Dünya, 24 Mayıs 1971.

13 “Doğuda Deprem 1000 Ölü Var”, Tercüman, 24 Mayıs 1971.
} 
Depremi ${ }^{14}$ de göz önünde bulundurulacak olunursa Bingöl Depremi'nin şok etkisi çok daha iyi anlaşılabilir. Hal böyle iken, Türkiye'nin Bingöl Depremi karşısında nasıl bir afet yönetimi uyguladığı soru işaretidir. Bingöl Depremi'ni tarihsel açıdan inceleyen bu çalışmanın amacı bu soru işaretine cevap vermenin yanı sıra depremin meydana gelişini, etkisini, yapılan iç, dış yardımları ve yardımlar sırasında yaşanan aksaklıkları, sorunları ortaya koymaktır.

\section{Depremin Meydana Gelişi, Etkileri, Hasar ve Zayiat}

Bingöl'de 21 Mayıs 1971 cuma günü saat 11.26'da hasar ve can kaybına neden olmayan orta şiddette bir deprem meydana gelmiştir. Büyük depremin habercisi niteliğindeki bu deprem sonucunda bazı resmi binalarda sadece hafif çatlamalar oluşmuştur. ${ }^{15} \mathrm{Bu}$ depremin ertesi günü yani 22 Mayıs'ta saat 18.45 'te merkez üssü Bingöl şehir merkezine yalnızca $10 \mathrm{~km}$ uzaklıkta olan aletsel büyüklüğü 6.8 şiddetinde daha büyük bir deprem meydana gelmiştir. ${ }^{16}$ Yapılan hesaplamalara göre depremin etki alan 12.000 km²' dir. ${ }^{17}$ Deprem; Van, Elazı ğ ve Urfa' da şiddetli; Trabzon, Diyarbakır, Erzurum, Gaziantep, Adana, Siirt ve Muş'ta orta; Samsun, Malatya ve Iğdır'da hafif olarak hissedilmiştir ${ }^{18}$. Çevre illerden en çok Elazı ğ' $1 n$ Palu ilçesini etkilemiştir. ${ }^{19}$

12 Mayıs 1971 Burdur Depremi'nin yaraları henüz sarılmadan meydana gelen bu depremden Türkiye biraz geç haberdar olmuştur. Deprem, PTT binasını ve elektrik santralini yıkarak Bingöl'ü hem karanlığa mahkûm etmiş hem de Bingöl'den bir müddet haber alınamamasına neden olmuştur. Dolayısıyla uzun saatler Bingöl ile irtibat kurulamamıştır. ${ }^{20}$ Depremin ortaya çıkardığı hasar hakkında ilk bilgilere askeri telsizlerle yapılan muhabere sonucunda ulaşılmıştır. $^{21}$ Bingöl ile telefon bağlantısı ancak depremin ertesi günü saat 4.00 'da kurulabilmiştir. ${ }^{22}$ Telefon bağlantısının kurulmasıyla birlikte depremin etkisinin ne denli büyük olduğunu anlaşılmıştır. Bundan sonra deprem hem ulusal hem de uluslararası basında büyük bir yankı yaratmıştır.

Volume 12

Bingöl'de depremin meydana geldiğini çok ayrıntılı olmamakla birlikte ilk haber veren ulusal gazeteler Son Havadis ve Hürriyet Gazeteleri olmuştur. ${ }^{23}$ Matbaalarının zarar görmesi nedeniyle yerel gazetelerden Bingöl ve İkbal Gazeteleri yayın hayatına bir süreliğine ara vermek zorunda kalırken; Bingöl Gazetesi, 31 Mayıs'ta, İkbal Gazetesi ise 10 Haziran'da yayın hayatına kaldığ yerden devam edecektir. ${ }^{24}$ Dolayısıyla depremle ilgili ilk haberleri Türkiye, ulusal basın aracılığıyla öğrenmek zorunda kalmıştır.

1412 Mayıs 1971 tarihinde meydana gelen 5.9 büyüklüğündeki Burdur Depremi’nde onlarca kişi yaşamını yitirirken 3.227 bina hasar almıştır. "Burdurun \%85'i Yıkıldı", Milliyet, 13 Mayıs 1971; Güler Özyıldıran, "1971 Burdur Depremi Sonrası İmar Çalışmaları", Uluslararası Burdur Deprem ve Çevre Sempozyumu, Burdur, 7-9 Mayıs 2015, s. 313.

15 “İlimizde dün deprem oldu can ve mal kaybı olmadı", Ikbal, 22 Mayıs 1971; "Dün ilimizde orta şiddette bir deprem oldu”, Bingöl, 22 Mayıs 1971.

16 "Bingöl ve çevresindeki depremde ölü sayısı bin civarında", Dünya, 24 Mayıs 1971; Sezer, agm, s. 38. Depremin 30 saniye kadar sürdüğü iddia edilmiştir. "Bingöl'de can ve mal kaybı var”, Hürriyet, 23 Mayıs 1971.

${ }_{17}$ Cumhurbaşkanlığ l Cevdet Sunay Arşivi (CCSA), Yer No: 5/9-12, Fihrist No: 9852-139.

18 “Haber gelen yerlerde ölü sayısı 800’ü buldu”, Hürriyet, 24 Mayıs 1971; “Ölü Sayısı Yükseliyor”, Akşam, 24 Mayıs 1971.

19 “Depremde ölü sayısı 842’ye yükseldi”, Akşam, 25 Mayıs 1971.

20 "Haber gelen yerlerde ölü sayıs1 800'ü buldu”, Hürriyet, 24 Mayıs 1971.

21 “Haber gelen yerlerde ölü sayısı 800'ü buldu”, Hürriyet, 24 Mayıs 1971; “Bingöl'de can ve mal kaybı var”, Hürriyet, 23 Mayis 1971.

22 “Doğu'da Deprem”, Tercüman, 24 Mayıs 1971.

23 “Güney Doğu Anadolu beşi gibi sallandı", Hürriyet, 23 Mayıs 1971; "Doğu Anadoluda Büyük Deprem”, Son Havadis, 23 May1s 1971.

24 "Deprem sebebiyle neşrine ara veren gazetemiz bugün neşre başladı", Bingöl, 31 Mayıs 1971; "Bingöl Depremi Ağır Tahribat Yaptı”, İkbal, 10 Haziran 1971. 
Havanın aydınlanmasıyla 23 Mayıs'ta depremin bilançosu yavaş yavaş ortaya çıkmaya başlamıştır. Basının ortaya çıkan bilançoyu büyük bir korku ve panik havası içerisinde verdiği görülmektedir. Günaydın Gazetesi, "Depremin harabeye çevirdiği Bingöl'de Enkazların altı cesetlerle dolu" başlığını atmıştır. ${ }^{25}$ Hürriyet Gazetesi, "Bingöl Ylkıldl: Can Kaybı Çok" manşetiyle depremi okuyucularına duyurmuştur. ${ }^{26}$ Son Havadis de "Doğu'da Büyük Deprem: Bin Ölü Var" manşetiyle sayısal verilere yer vermek suretiyle ${ }^{27}$ depremin şiddetini anlatmaya çalışmıştır. Tercüman Gazetesi'nin "Bingöl ve köyleri harap oldu" 28 ve Milliyet Gazetesi'nin "Bingöl'de Deprem: Bine Yakın Ölü Var"29 manşetleri korkuyu ve paniği açıkça yansıtmaktadır. Dünya basınından The Times Gazetesi Bingöl Depremi'ne büyük ilgi göstererek depremi sütunlarına taşımıştır. Gazete, depremde binden fazla kişinin öldüğüne ve 700'den fazla kişinin de yaralandığına inanıldığını aktarmıştır. Ayrıca The Times, yaptığı haberde İsrail'in İstanbul Başkonsolosu Efraim Elrom'un depremin olduğu gün öldürüldüğünü aktararak depremle birlikte Türkiye'nin şok üstüne şok yaşadığını kaydetmiştir. ${ }^{30}$

Depremin haber alınmasından itibaren başta Elazı ̆̆ olmak üzere çevre illerdeki askeri ve sivil ekipler Bingöl'e yardıma koşmuştur. ${ }^{31}$ Deprem sırasında elektrik santralinin zarar görmüş olması ve daha sonra başlayan şiddetli yağmur arama kurtarma çalışmalarını zorlaştıran etmenler olmuştur. ${ }^{32}$ Havanın 1şımasıyla birlikte can kaybı, hasar ve zayiat konusunda rakamlar ifade edilmeye başlanmıştır. Akşam Gazetesi'nin verdiği ilk bilgilere göre, enkaz altından çıkartılan can kaybı sayıs1 702 olup yaralı sayısı ise 1.000'dir. Birçok köyle henüz bağlantının kurulamadığını ifade eden Gazete, sayısının daha da artmasından korkulduğunu ifade etmiştir. Deprem sonucunda binaların ise \% 90'ı oturulamaz duruma gelmiştir. Elazı̆̆'ın Palu ilçesi de depremden etkilenmiş ve ilk belirlemelere göre, burada 130 ev tamamen yıkılmış ve 3 kişi ölmüştür. Kiğı'nın Batıayaz köyünde de bir kadın deprem sırasında yaşadığ 1 korkudan hayatını kaybetmiştir. ${ }^{33}$ Akşam Gazetesi, 25 Mayıs'ta ölü sayısının Bingöl'de 842'ye, Palu'da ise 18'e yükseldiğini duyururken diğer yandan Bingöl'ün 10 köyü ile hemen irtibat kurulamamıştır. Gazete, bu köylere ulaşılması halinde can kaybı sayısının daha da artacağından korkulduğunu kaydetmiştir. ${ }^{34}$ Enkaz kaldırma çalışmalarının hızlanmasıyla birlikte nihai rakamlar belirmeye başlamıştır. Buna göre hayatını kaybedenlerin sayısı 861'e yükselirken ölümlerin dağılımı şu şekildedir: Bingöl şehir merkezinde 321, merkez köylerinde 500 ve ilçelerde de 15 kişi ölmüştür. Elazığ'ın Palu ilçesinde de 20 kişinin öldüğü aktarılmıştır. ${ }^{35}$

Depremin merkez üssünün Bingöl şehir merkezi olması nedeniyle en çok zarar Bingöl şehir merkezi ve köylerinde yaşanmıştır. Dere-i Kasaran, Erzurum, Cumhuriyet ve Kıbrıs mahallelerindeki bütün yapılar yıkılmıştır. ${ }^{36}$ Deprem karşısında neredeyse bütün resmi binalar

\footnotetext{
25 "Depremin harabeye çevirdiği Bingöl'de Enkazların altı cesetlerle dolu”, Günaydın, 24 Mayıs 1971.

26 "Bingöl Yıkıldı: Can Kaybı Çok", Hürriyet, 24 Mayıs 1971.

27 “Doğu'da Büyük Deprem: Bin Ölü Var”, Son Havadis, 24 Mayıs 1971.

28 "Bingöl ve köyleri harap oldu", Tercüman, 24 Mayıs 1971.

29 "Bingöl'de Deprem: Bine Yakın Ölü Var", Milliyet, 24 Mayıs 1971.

30 "More than 1,000 believed killed as earthquake flattens Turkish town", The Times, 24 May1s 1971.

31 "Enkazların altı cesetlerle dolu”, Günaydın, 24 Mayıs 1971; "Bingöl'de can ve mal kaybı var", Hürriyet, 23 Mayıs 1971; "Ölü Sayısı Yükseliyor”, Akşam, 24 Mayıs 1971.

32 “Haber gelen yerlerde ölü sayısı 800'ü buldu”, Hürriyet, 24 Mayıs 1971.

33 “Ölü Sayısı Yükseliyor”, Akşam, 24 Mayıs 1971.

34 “Depremde ölü sayıs1 842'ye yükseldi”, Akşam, 25 Mayıs 1971.

35 "Bingöl'de can kaybı 861'e yükseldi”, Akşam, 26 Mayıs 1971.

36 “Deprem Bingöl'ü Viran Etti”, Bingöl, 31 Mayıs 1971; “Enkaz olan şehir”, Tercüman, 24 Mayıs 1971.
} 
ağır hasar alarak yıkılmıştır. ${ }^{37}$ Vilayet konağı, lise binası, cezaevi, hastane, ebe ve hemşire okulu, PTT, il özel idaresi ve iş bankası binaları yıkılan resmi binalar içerisinde önemli olanlarıydı. ${ }^{38}$

Depremin neden olduğu hasar ve zayiat resmi kayıtlara da geçmiştir. İmar ve İskân Bakanlığı yetkililerince yapılan hasar tespit çalışmaları sonucunda toplamda 878 kişinin can verdiği tespit edilmiştir. Bingöl şehir merkezinde 324, 88 merkez köyünde 545, Solhan ilçesinin 9 köyünde 6, Karlıova ilçesinde 1 ve Kiğı' da 1 kişi yaşamını yitirmiştir. ${ }^{39}$ Fakat depremzedelere göre, bu resmi rakamlar gerçeği yansıtmamaktadır. Depremden hemen sonra halkın bir kısmı yetkililere haber vermeden cenazelerini alarak çevre illere götürüp defnetmişlerdir. Bir kısmı da yine yetkililere haber vermeden köylerde defin işlemlerini tamamlamışlardır. Onlara göre, gerçek can kaybı sayısı yaklaşık 2.000 civarıdır. ${ }^{40}$ Dolayısıyla depremzedelerin bu resmi rakamlara kuşku ile baktığı görülmektedir.

Resmi kayıtlara göre, Bingöl genelinde 5.219 bina ağır hasar, 3.080 bina orta hasar ve 3.111 bina ise az hasar almıştır. Ağır hasar olan binalardan 1.734'ü şehir merkezinde, 2.769'u merkez köylerinde, 80'i Genç ilçe merkezinde, 237'si Genç ilçesinin köylerinde, 55'i Solhan ilçe köylerinde, 260'1 Karlıova ilçe köylerinde, 84'ü ise Kiğı ilçe köylerinde bulunuyordu. Orta hasarlı binaların da 950'si şehir merkezinde, 1.333'ü merkez köylerinde, 120'si Genç ilçe merkezinde, 233'ü Genç ilçe köylerinde, 122'si Solhan ilçe köylerinde, 143'ü Karlıva ilçe köylerinde ve 179 'u Kiğ ilçe köylerinde yer almıştır. Az hasarlı binaların yerleşim yerlerine göre dağılımı ise yine ağır hasar ve orta hasar kategorisinde olduğu gibi benzer niteliktedir. ${ }^{41}$ Anlaşılacağı üzere, depremde hem can hem mal açısından en fazla kayıp Bingöl'ün merkez köylerinde verilmiştir.

Yine depremzedeler hasar kayıtlarında hataların yapıldığını iddia ederek sürekli itirazlarda bulunmuşlardır. Yetkililer tarafından ağır hasarlı binaların orta ya da az hasarlı, az hasarlı binaların da ağır hasarlı gösterildiğine inanan depremzedeler, kendilerine haksızlık yapıldığı hususunda resmi kurumları sürekli uyarmışlardır. Hasar tespitlerinin yeniden yapılmasını istemişlerdir. ${ }^{42}$ Fakat hasar tespiti yeniden yapılmamıştır. ${ }^{43}$ Kısacası depremzedelere göre, hasar ve zayiat tespitinde büyük aksaklık ve haksızlıklar yaşanmıştır. Bütün uyarı ve şikâyetlere rağmen de bunlar düzeltilmemiştir.

Bingöl ağır bir tahribat almıştı. 23 Mayıs 1971 sabahı enkaz alanını inceleyen Milliyet Gazetesi'nden Mete Akyol, gördüğü manzarayı şu sözlerle anlatmıştır: "Bingöl, tamamen yıkılan Cumhuriyet mahallesi, üstünden bastırılmış̧̧asına yamru yumru olan dört katll yatılı Sağllk Okulu, katları üstüne yığılan yatılı lise binası ve yarısına yakın bir bölümü çöken Devlet Hastanesi ile kaderine yenilmiş olarak güneşle birlikte gözler önüne çıktı...Burası Bingöl Yatılı Să̆llk Okulu. Üstünden kuvvetlice basilmış bir kartondan maket gibi yamru yumru olmuş bu sözde bina içinde $158 \mathrm{klz}$ öğrencinin ebe olmak için çalıştı̆̆l, yattı̆̆ bir yer. Buradan yüz kişi să̆ olarak kurtarılmış, 3 kişinin de cesetleri çıkarılmış. 'Ötekiler? Ya Ötekiler' Bingöllüler

\footnotetext{
37 "Devlet binaları kağıt gibi yıkıldı", Milliyet, 25 Mayıs 1971; "55 kız öğrenci enkaz altındaydı", Milliyet, 24 Mayıs 1971.

38 "Enkaz olan şehir", Tercüman, 24 Mayıs 1971.

${ }^{39}$ CCSA, Yer No: 5/9-12, Fihrist No: 9852-126.

40 “Bingöl Depremi Ağır Tahribat Yaptı”, İkbal, 10 Haziran 1971; “Ölü Sayısı”, Tercüman, 26 Mayıs 1971.

${ }^{41}$ CCSA, Yer No: 5/9-12, Fihrist No: 9852-126.

42 "Hasar Listeleri Açıklandı", Ikkbal, 26 Haziran 1971; A. Hikmet Yurtsever, "Böyle olmaz Sayın Bakanım”, İkbal, 29 Haziran 1971.

43 “Hasar tespiti yeniden yapılmayacak", İkbal, 9 Temmuz 1971.
} 
çaresizlik içinde boyunlarını büküp konuşuyorlar: 'Hele bir gelsin kurtarma ekipleri' diyorlar. 'Onlar da çıkar'," ${ }^{4}$

Yine Mete Akyol, enkaz alanını gezerken deprem felaketinin neden olduğu acıklı bir olaya şahit olmuştur: "Cumhuriyet mahallesinin meydanlık bir yerinde kadınlı erkekli bir kalabalık gördük. Gittik baktık, kalabalık çemberinin ortasında yerde, tam 12 kişinin cesetleri sıralanmıştı. Beşi büyük, yedisi çocuktu yerde yatanların. Sonra bir kamyon getirdi mahallelilerden biri. Yerdeki cesetleri tek tek kamyona yüklemeye başladılar. Önce büyükler alındı kamyona. Sira çocukların cesetlerini yüklemeye gelince garip bir olay oldu. Çocuğunu kucağına alan her kadın, birbirlerine dönerek 'önce sen ver' demeye başladl. Uzun sürdü bu 'önce sen ver' sözleri. Kamyondan erkekler 'hadi, hadi, hadi' diye bağırdılar, ancak böyle alabildiler çocukları analarının kucaklarından". ${ }^{45}$

Bingöl'ün genelinde yapıların \% 70'inin zarar gördüğü yıkıcı felaket karşısında Başbakan Nihat Erim, depremin ertesi günü yani 23 Mayıs sabahı Sağlık Bakanı Türkan Akyol, İçişleri Bakanı Hamdi Ömeroğlu, İmar ve İskân Bakanı Selahattin Babüroğlu ile birlikte askeri uçakla deprem alanını yerinde görmek üzere Bingöl'e gelmiştir. ${ }^{46}$ Bingöl Depremi'nin olduğu gün Türkiye'nin şok edici bir olay daha yaşadığı görülmektedir. 17 Mayıs'ta THKP-C üyesi Mahir Çayan ve arkadaşları tarafından kaçırılan Türkiye'deki İsrail Başkonsolosu Efraim Elrom öldürülmüştü. ${ }^{47} \mathrm{Bu}$ iki olayın aynı güne denk gelmesi karşısında Nihat Erim, Bingöl'e hareket etmeden önce, üzüntüsünü şöyle dile getirmiştir: "Bugün iki üzüntümüz vardır. Birincisi, Burdur'dan kisa bir süre sonra Bingöl ve çevresinde yeni deprem felaketinin meydana gelmesidir... İkinci üzüntümüz, İsrail Başkonsolosunun öldürülmesi olayldır. Onu öldürenler Türk olamazlar. Çünkü Türkiye'nin menfaatleri aleyhine cürüm işlemişlerdir. Olaydan duyduğumuz üzüntüyü dün sabah İsrail Başbakanına gönderdiğim bir mesajla bildirdim". 48 Buna ilave olarak 31 Mayıs 1971'de THKP-C örgütünden Mahir Çayan ve Hüseyin Cevahir'in Maltepe'de binbaşının kızı Sibel Erkan'ı rehin almıştır. Bu durum da hükümeti ve halkı oldukça meşgul etmiştir. Günlerce süren bu rehin krizi nedeniyle basın Bingöl Depremi'ni unutarak ilgisini bu yöne çevirmiştir. Öte yandan gündemde başkaca diğer sorunların da olması genel olarak Bingöl Depremi'nin, ulusal basında fazla konuşulmamasına neden olmuştur. ${ }^{49}$

Bingöl'e gelerek deprem alanını gezen Başbakan Nihat Erim, gördüğü manzara karşısında "Bingöl hazin bir tablo" şeklinde çarpıcı bir tespitte bulunmuştur. İncelemelerini tamamladıktan sonra radyoda yaptığı konuşmada "Yıkıntıları mahalle mahalle gezdik. Resmi binalardaki zararları anlamaya çalıştık. Bingöl merkezinde zarar çok büyük. Halkın büyük bir kısmı kerpiç ve usulüne göre yapılmamış binalara sahip oldukları için çok zarar görmüşlerdir. Kerpiç binalar hemen hemen tamamen kullanılamayacak hale gelmiştir. Yığma binaların içinde ayakta kalanı çok azdır. Resmi binalarda da büyük tahribat göze çarpmaktadır. Bunun nedenini de araştıracağız..." ${ }^{50}$ şeklinde izlenimlerini aktarmıştır. Başbakan Erim, depremin etkisinin bu

\footnotetext{
44 "55 kız öğrenci enkaz altındaydı", Milliyet, 24 Mayıs 1971.

45 “55 kız öğrenci enkaz altındaydı”, Milliyet, 24 Mayıs 1971.

46 “Erim ve Bazı Bakanlar Bingöl'e gitti”, Son Havadis, 24 Mayıs 1971; “Başbakan Erim, Bingöl'de”, Tercüman, 24 Mayis 1971.

47 “Hunharca Öldürdüler", Hürriyet, 24 Mayıs 1971.

48 "Nihat Erim", Hürriyet, 24 Mayıs 1971; "Kidnapped Israel envoy found murdered", The Times, 24 Mayıs 1971. Milliyet Gazetesi muhabiri Bingöl'e gelen Başbakan Nihat Erim ile uçakta yaptığı konuşmada üst üste gelen felaketler karşısında Erim'in üzgün olduğunu ve can kayıpları karşısında gözlerinin yaşlığı olduğunu gözlemlemiştir. "Devlet Binaları Kâğıt Gibi Yıkıldı”, Milliyet, 25 Mayıs 1971.

${ }^{49}$ Gazete haberleri için Bkz. Dünya, 31 Mayıs 1971; Tercüman, 31 Mayıs 1971; Akşam, 1 Haziran 1971; Hürriyet

31 Mayıs 1971; Son Havadis, 2 Haziran 1971; Dünya, 3 Haziran 1971.

50 "Erim: Bingöl, hazin bir tablo", Akşam, 24 Mayıs 1971.
} 
denli yıkıcı olmasını kerpiç ve usulüne göre yapılmamış binalara bağlamıştır. Yapılan araştırmalar sonucunda da Erim'in ilk gözleminin ne kadar isabetli olduğu ortaya çıkacaktır.

Cumhuriyet Halk Partisi (CHP) de incelemelerde bulunmak üzere depremin ikinci günü Bingöl'e bir heyet göndermiştir. CHP Genel Sekreteri Şeref Bakşık başkanlığındaki heyette partinin merkez yürütme kurulu üyesi Yılmaz Alpaslan ve Millet Meclisi grup üyesi Mehmet Aytu yer almıştır. Bakşık incelemeleri sonucunda özetle, "Ülkemizin jeolojik yapısı dolayısıyla Bingöl de deprem gördü. Acımız büyük, can kaybımız büyük, mal kaybımız büyük. Gerekli gördügümüz tedbirlere görevlilerin dikkatini çekerek, acıları azaltmaya çaba gösteriyoruz" şeklinde konuşmuştur. ${ }^{51}$ Adalet Partisi (AP) de üç kişiden oluşan bir heyetini deprem bölgesine yollamıştır. Bunun yanı sıra AP Genel Başkanı Süleyman Demirel Bingöl Valisi Metin Dirimtekin ile Bingöl Belediye Başkanı Faik Ertuğrul ve Bingöl AP İl Teşkilatı Başkanı Halit Ziya Ünal'a birer telgraf göndererek deprem afetinden duyduğu üzüntüyü dile getirmiş ve Bingöllülere başsağlığı dilemiştir. ${ }^{52}$ Cumhurbaşkanı Cevdet Sunay da Bingöl Valisi'ne ve Belediye Başkanı'na birer taziye mesajı göndererek üzüntüsünü belirtmiştir. ${ }^{53}$ Son olarak deprem alanında incelemeler yapmak üzere gelenler arasında Genel Kurmay Başkanı Memduh Tağmaç ve üç kuvvet komutanı da yer almıştır. ${ }^{54}$

$\mathrm{Bu}$ arada Başbakan Nihat Erim'in sözünü ettiği resmi binalardaki tahribatın nedenlerini araştırma işi hemen başlatılmıştır. Bayındırlık Bakanı Cahit Karakaş yıkılmış olan resmi ve diğer binalarda incelemelerin başladığını ve bu işte kusuru bulunması halinde müteahhitlerin belgelerinin iptal edileceğini açıklamıştır. ${ }^{55}$ Yapılan incelemelerin sonucunda Bingöl'de ağır hasar gören resmi binalar içerisindeki ebe okulu ile lise binasında kötü işçilik görüldüğü, kötü malzeme kullanıldığ 1 ve briketlerin ise tamamen ince kumdan olduğu tespiti yapılmıştır. Hatanın müteahhitten kaynaklandığı iddia edilmiş ve müteahhit Nizami Barutçu hakkında idari soruşturma açılmıştır. Aynı zaman da kontrolör hakkında da takibat yapılacağı duyurulmuştur.

Volume 12

Issue 5

October

2020 Öte yandan söz konusu müteahhidin belgesi iptal edilmiştir. Bakan Cahit Karakaş yaptığı basın açıklamasında tedbir olarak bundan sonra herkese müteahhitlik belgesinin verilmeyeceğini ve müteahhitlik kurumunun sslah edileceğini aktarmıştır. Aslında Türkiye nüfusunun \% 70'inin deprem bölgesinde yaşadığına dikkatleri çeken Karakaş, Türkiye deprem bölgesi haritasının yanlış olduğunu ve yapıların deprem yönetmeliğine aykırı olarak inşaa edildiğini kaydetmiştir. 1968 yılında değiştirilen deprem bölgesi haritasına göre, birinci derece deprem alanı olarak gösterilen yerlerde hiç deprem olmamış, ikinci derece olarak gösterilen deprem bölgelerinde ise sık sık depremler meydana gelmiş̧ir. Örneğin, Bartın birinci deprem bölgesi sayılırken, Bingöl ikinci derece deprem bölgesi kabul edilmiştir. Bu durum karşısında Bakan Karakaş, derhal deprem haritasının değiştirileceğini açıklamıştır. Ayrıca mevcut deprem yönetmeliği de yapılan araştırmalar soncu yetersiz bulunmuştur. Bu durumda deprem yönetmeliğinin değiştirilmesine de karar verilmiştir. Yeni deprem yönetmeliği ile de bundan sonra binalar yapılırken binanın tip ve karakteri hususlarına ciddiyetle eğilecek ve her malzeme her bölgede rahatlıkla kullanılamayacaktır. İnşaatlarda kullanılacak malzemeler deprem risk bölgesine göre farklılık gösterecektir. ${ }^{56}$ Anlaşılan o ki hükümet yıkıcı Bingöl Depremi karşısında bir takım dersler

\footnotetext{
51 "Bingöl Belediye Başkanı: Formalite yardımı aksatıyor", Akşam, 25 Mayıs 1971.

52 "Bingöl çevresinde şiddetli bir deprem oldu", Dünya, 24 Mayıs 1971.

53 “Sunay'ın Mesajı", Akșam, 24 Mayıs 1971; CCSA, Yer No: 5/5-27, Fihrist No: 7058.

54 "Komutanlar Bingöl'de", Akşam, 29 Mayıs 1971.

55 "Deprem bölgesindeki inşaatlarda hatalı görülen müteahhitlerin belgeleri iptal edilecek", Akşam, 31 Mayıs 1971

56 "Nüfusumuzun \%70'i deprem bölgesinde", Akșam, 13 Haziran 1971; "Deprem yönetmeliğinin yetersizliği açıklandı", Dünya, 13 Haziran 1971; "Deprem bölgesi olarak gösterilen yerlerde hiç deprem olmamış, diğer yerlerde sık sık olmuş", Tercüman, 13 Haziran 1971. Bayındırlık Bakanı Cahit Karakaş'ın 13 Haziran 1971'de basına yaptığı konuşmanın tam metni için bkz. Millet Meclisi Tutanak Dergisi (MMTD), Dönem (D):3, Cilt (C):37, Toplantı (T):4, Birleşim (B): 116, s. 670-678 (28.05.1973).
} 
çıkartmıştır. Deprem tedbirleri anlamında hatalarının olduğunu fark ederek bunları düzeltme yoluna girmiştir.

23 Aralık 1972 tarihinde Bakanlar Kurulu aldığı kararla yeni Türkiye Deprem Bölgeleri Haritasını belirlemiștir. Bu kararın 15 Mayıs 1973 tarihinde resmi gazetede yayınlanmasıyla birlikte yürürlüğe girmiştir. ${ }^{57}$ Yeni haritada Bingöl, birinci derece deprem bölgesi olarak gösterilmiştir. ${ }^{58}$

\section{Yardım Çalışmaları ve Yaşanan Sorunlar}

Deprem felaketinin askeri telsizlerle öğrenilmesiyle birlikte depremzedelerin ilk yardımına Elazı̆̆ ve Bingöl garnizonlarındaki askeri birlikler koşmuştur. Özellikle Bingöl Garnizon Komutanı Albay İsmail Ülkü hızlıca harekete geçerek alaydaki bütün subay ve erleri arama kurtarma çalışmalarında seferber etmiştir. ${ }^{59}$ Fakat deprem bölgesi ile karayolu irtibatını sağlayan Bingöl-Genç arasındaki Murat Köprüsü'nün deprem esnasında yıkılmış olması çevre illerden gelecek yardımı geciktirmiştir. Bunun üzerine Elazı̆̆ Valisi Zekeriya Çelikbilekli köprünün tamiri için Bingöl'e bir köprücü bölüğü göndermiştir. ${ }^{60}$ Gecenin ilerleyen saatlerinde başlayan kurtarma çalışmaları tüm hızıyla sürerken bir yandan da deprem sırasında zarar gören telefon ve telgraf hatlarının onarılmasına, Ankara ve çevre illerle irtibat kurulmasına çalışılmıştır. ${ }^{61}$

Öte yandan havanın yağışlı olması ${ }^{62}$ ve elektriklerin kesik olması kurtarma çalışmalarını

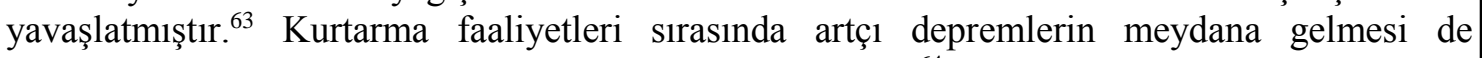
çalışmaları aksatmakla birlikte halkın moralini bozmuştur. ${ }^{64}$ Havanın aydınlanmasıyla birlikte kurtarma çalışmalarına hız verilmiştir. Ekiplere yerel halk da katılmıştır. Bingöllü erkekler ellerine geçirdikleri kazmalar, kürekler ve hiçbir şey yoksa elleriyle arama çalışmalarına katılmışlardır. ${ }^{65}$ Aynı zamanda sabahın erken saatlerinde Bingöl'e ulaşan kurtarma ekiplerinin sayısı artmıştır. Elazı ğ Valisi Zekeriya Çelikbilekli, 7 hemşire, 7 sağlık memuru, 2 ambulans ve ağır yaralıları Elazığ Hastanesi'ne taşımak için 4 otobüs göndermiştir. Bingöl Devlet Hastanesi'nin tamamen yıkılması sebebiyle 100 yataklı bir seyyar hastane deprem bölgesine ulaştırılmıştır. Hasta nakillerinde ve kurtarma faaliyetlerinde bütün resmi ve özel araçlardan faydalanılmıştır. Bunun dışında Elazığ Belediyesi, enkaz kaldırmak için araç gereç ve işçi göndermiştir. ${ }^{66}$ Erzurum Atatürk Üniversitesi'nden 200 öğrenci de gönüllü olarak Bingöl’e gelip arama kurtarma çalışmalarına katılmıştır. ${ }^{67}$

Sağlık ve Sosyal Yardım Bakanlığınca çevre illerden harekete geçirilen sağlık ekipleri gece saat 01.00'dan itibaren Bingöl'e ulaşmış ve yaralıların tedavisine başlamıştır. Bingöl'el Diyarbakır ve Elazığ'dan da hekim gönderilmiştir. Özellikle Diyarbakır’dan çok sayıda öğretim

\footnotetext{
${ }^{57}$ Bülent Özmen, "Türkiye Deprem Bölgeleri Haritalarının Tarihsel Gelişimi”, Türkiye Jeoloji Bülteni, C.55, S.1, Ocak 2012, s. 49.

58 Bülent Özmen-Süleyman Pampal, "Türkiye Deprem Bölgeleri Haritalarının Evrimi”, 4. Uluslararası Deprem Mühendisliği ve Sismoloji Konferansl, Anadolu Üniversitesi, Eskişehir 11-13 Ekim 2017, s. 202.

59 “Büyük Deprem”, Son Havadis, 23 Mayıs 1971; "Bingöl'e yardım yağıyor”, Günaydın, 24 Mayıs 1971; "Deprem Bingöl'ü viran etti”, Bingöl, 31 Mayıs 1971; CCSA, Yer No: 5/9-12, Fihrist No: 9852-124.

60 "Enkaz olan şehir", Tercüman, 24 Mayıs 1971.

${ }^{61}$ CCSA, Yer No: 5/9-12, Fihrist No: 9852-124.

62 "Enkazaların altı cesetlerle dolu", Günaydın, 24 Mayıs 1971.

63 “Doğu'da Deprem”, Tercüman, 24 Mayıs 1971. Bingöl'ün cadde ve meydanlarına depremden ancak 3 gün sonra elektrik verilebilmiştir. "Bingöl'ün sokak ve caddeleri aydınlandı”, Dünya, 26 Mayıs 1971.

64 "11 kişiyiz, 4 kişi öldü, yaralıyı", Tercüman, 25 Mayıs 1971.

65 “Bingöl'de Deprem: Bine Yakın Ölü Var", Milliyet, 24 Mayıs 1971.

66 "Enkaz olan şehir”, Tercüman, 24 Mayıs 1971; CCSA, Yer No: 5/9-12, Fihrist No: 9852-124.

67 “200 Öğrenci Deprem Bölgesinde”, Dünya, 24 Mayıs 1971.
} 
üyesi hekim Bingöl'e gelerek yaralıları tedavi etmişlerdir. ${ }^{68}$ Depremde şehrin su şebekesi tamamen zarar gördüğü için şehre su tankerleri sevk edilmiştir. Sağlık Bakanlığının emri ile suların klorlanması yoluna gidilmiştir.

Deprem bölgesine ilk andan itibaren çeşitli yardımlar yapılmıştır. Bakıldığında gelen yardımları getiren uçaklar önce Elazığ Havalimanı'na inmekte ve buradan diğer vasıtalarla yardımlar Bingöl'e ulaştırılmaktadır. ${ }^{69}$ Kızılay Genel Merkezi depremin ertesi sabahı iki askeri uçakla deprem bölgesine 1.500 çadır, 3.000 battaniye ile ilaç ve tıbbi malzeme ulaştırmıştır. Ayrıca Erzurum transit deposundan da 900 çadır, 870 battaniye ve 9.000 ekmek ilk yardım olarak gönderilmiştir. Kızılay Erzurum Kan Merkezi sağlık ekibi de gece deprem bölgesine beraberinde yeterli miktarda kan ve gerekli tıbbi malzeme ile ulaşmıştır. ${ }^{70}$ Civar illerden özellikle Muş, Elazığ, Diyarbakır, Siirt, Malatya, Erzurum ve Bitlis’ten ilk yardım amaçlı birçok gıda malzemesi gelmiştir. ${ }^{71}$ Örneğin, Siirt'ten 11 kamyon dolusu yiyecek maddesi gönderilmiştir. 11 kamyonun içinde $500 \mathrm{~kg}$ alç1, $950 \mathrm{~kg}$ peynir, $850 \mathrm{~kg}$ zeytinyağı, 21 ton un, 1,5 ton çay şekeri, 10 bidon gaz yağı, $500 \mathrm{~kg}$ helva ve zeytin, 2 ton vita (yağ), $900 \mathrm{~kg}$ çeşitli yiyecek maddeleri ve 90 $\mathrm{kg}$ sigara vardı. Ayrıca Kurtalan Kaymakamlığınca $250 \mathrm{~kg}$ çeşitli yiyecek maddesi, 1.700 ekmek ve Siirt Battaniyeciler Derneğince 100 battaniye ve Baykan Kaymakamlığı'ndan 300 kg çeşitli yiyecek maddeleri yollanmıştır. ${ }^{72}$ Ulaşımın karayoluyla sağlanamadığı dağ köylerine ise yardımlar, helikopterlerle ulaştırılmaya çalışılmıştır. ${ }^{73}$ Jandarma Genel Komutanlığı'nın 2 ve Almanya'nın Bingöl için gönderdiği 2 helikopter olmak üzere toplam 4 helikopter bu işte kullanılmıştır. ${ }^{74}$

İmar ve İskân Bakanlığı Bingöl Valiliği emrine 500.000 liralık ilk ve acil yardımdan başka Muş deposundan 50 çadır, 100 yatak, 120 yastık, 25 yorgan, 50 battaniye, bir mutfak çadırı, 50 kg yağ, 10 çuval bezelye ve $400 \mathrm{~kg}$ süt tozunu deprem bölgesine sevk etmiştir. ${ }^{75}$

Volume 12

Deprem bölgesinde en çok sıcak yemek sıkıntısı çekildiği için ${ }^{76}$ Kızılay Genel Merkezi, Sivil Savunma İdaresi ve Vakıflar Genel Müdürlügünce ikişer tane seyyar aş ocağı bölgede faaliyete geçirilmiş ve uzun süre halka sıcak yemek dağıtılmıştır. ${ }^{77}$ Öte yandan depremzedelerin diğer bir sıkıntısı su olmuştur. Deprem sırasında su boruları patlamış ve sular çamurlu akmaya başlamıştır. Yetkililer depremzedeleri bu suyu kullanmamaları konusunda defalarca uyarmıştır. Elazı̆̆ ve diğer illerden getirilen sular dağıtılarak bu suların kullanılmaması istenmiştir. ${ }^{78}$ Depremden sonra bir enkaz yığını haline gelen Bingöl'de bir salgın hastalığın baş göstermesinden korkulduğu için sağlık ekipleri aşı çalışmalarına başlamıştır. ${ }^{79}$ Bingöl'e yapılan çeşitli yardımlar ilerleyen günlerde de artarak devam etmiştir. ${ }^{80}$

\footnotetext{
68 "Yıkılan Ev Sayısı", Akşam, 24 Mayıs 1971.

69 "Siddetli bir sallantı daha", Son Havadis, 25 Mayıs 1971.

70 “Doğu'da Deprem”, Tercüman, 24 Mayıs 1971; “Kızılay ekibi deprem bölgesinde” Son Havadis, 24 May1s 1971.

71 “Deprem Bingöl'ü viran etti”, Bingöl, 31 Mayıs 1971.

72 “11 Kamyon Yiyecek Maddesi Bingöl’e Gönderildi”, Günaydın, 24 Mayıs 1971; “11 Kamyon Yiyecek Gönderildi”, Akşam, 24 Mayıs 1971.

73 "Helikopterler malzeme taşıyor", Akşam, 25 Mayıs 1971.

${ }^{74}$ CCSA, Yer No: 5/9-12, Fihrist No: 9852-125.

75 "Bingöl çevresinde şiddetli bir deprem", Dünya, 24 Mayıs 1971.

76 "Bingöl'den alınan ilk haberler", Akşam, 24 Mayıs 1971.

${ }^{77}$ CCSA, Yer No: 5/9-12, Fihrist No: 9852-125.

78 “Şiddetli bir sallantı daha”, Son Havadis, 25 Mayıs 1971; "Enkazların altı cesetlerle dolu”, Günaydın, 24 Mayıs 1971.

79 "Salgın Hastalıktan Korkuluyor", Akşam, 28 Mayıs 1971.

80 "Deprem”, Son Havadis, 26 Haziran 1971; "Bingöl deprem bölgesine 10 bin çadır gönderildi”, Dünya, 27 Mayıs 1971.
} 
Deprem neticesinde birçok çocuk sahipsiz kalmıştır. Korunmaya muhtaç çocukları tespit etmek, gerekli incelemelerde bulunmak ve zorunlu tedbirleri almak üzere Türkiye Çocuk Esirgeme Kurumu Başkanı Ali Rıza Zorluoğlu, derhal Bingöl'e giderek çalışmalara başlamıştır. ${ }^{81}$ Elazığ Korunmaya Muhtaç Çocukları Birliği de kimsesiz kalmış 20 çocuğa sahip çıkmıştır. Diğer yandan bazı vatandaşlar da kimsesiz çocukları sahiplenmek için Bingöl Valiliği’ne başvurmuştur. ${ }^{82}$

Çeşitli kurum ve kuruluşlar da depremzedelere yardım için harekete geçmiştir. Türk Silahlı Kuvvetleri 150.000 lira toplayarak yardımda bulunmuştur. ${ }^{83}$ Ankara Ticaret Odası depremde harcanmak üzere 100.000 lira bağışlamıştır. Berec Firması da bir miktar maddi yardım yapmıştır. ${ }^{84}$ Ankara Sıkıyönetim Komutanlığı bir bildiri yayınlayarak Bingöl ve Burdur'daki depremzedelere yardım için Yardımseverler Derneği'ne bağış yapılmasını rica etmiştir. ${ }^{85}$ Ankara Valiliği bir yardım kampanyası başlatmıştır. ${ }^{86}$ Türkiye Öğretmenler Sendikası Genel Merkezi 5.000 liralık bağışta bulunmuştur. ${ }^{87}$ Hürriyet Gazetesi 7 kamyon yardım malzemesi göndermiştir. ${ }^{88}$ En büyük yardım kampanyası Türk-İş Sendikası tarafından başlatılmıştır. Sendika yönetimi teşkilatına bir genelge göndererek sendika üyesi bütün işçilerin birer yevmiyelerini depremzedelere bağışlamalarını istemiştir. Kampanya sonunda 10 milyon lira toplanacağı açıklanmıştır. ${ }^{89}$ Türk-İ̧s Sendikası'nın açtığı bu yardım kampanyasına daha sonra uluslararası işçi kuruluşları da dâhil olmuştur. Amerikan İşçi Sendikaları Konfederasyonu 1.000 dolar ve Alman İşçi Sendikaları Konfederasyonu 50.000 mark göndermiştir. ${ }^{90}$

Nihat Erim Hükümeti de depremin yaralarını bir an önce sarmak ve depremzedelere yardımcı olmak için birçok tedbire başvurmuştur. 2 Temmuz 1971 tarihinde Bakanlar Kurulu'nda alınan kararla depremde zarar gören esnaf ve küçük zanaatkârlarla bunların kurdukları dernek, birlik, kooperatif ve ortaklarının Türkiye Halk Bankası'na olan borçları ertelenmiştir. ${ }^{91}$ Bununla da yetinmeyen Hükümet, 25 Ekim 1971'de aldığı kararla çiftçilerin Ziraat Bankası ve Tarım ve Kredi Kooperatiflerine olan borçlarını taksitlendirmiştir. ${ }^{92} 19$ Haziran 1971 tarihinde de geliri deprem bölgelerinde kullanılmak üzere tekel ürünlerine $\% 15$ oranında zam yapılmıştır. ${ }^{93}$ Son Havadis Gazetesi'nden Adviye Fenik, bu zamma tepki göstermiştir. Vatandaşın sürekli gelen zamlardan bunaldığını ifade ederek tekel zammını masum göstermek adına bu zammın adının afet zammı verildiğini iddia etmiştir. ${ }^{94}$

Bakanlar Kurulu'nun aldığ önemli bir diğer tedbir ise Bingöl ve diğer depremlerin izlerini bir an önce silmek adına afet çevresindeki 9 ilde hür türlü işyerinde grev ve lokavtı yasaklamak olmuştur. Bu iller; Denizli, Burdur, Afyon, Kütahya, Bingöl, Elazığ, Maraş, Van vel

\footnotetext{
${ }^{81}$ CCSA, Yer No: 5/5-27, Fihrist No: 7036.

82 "Valimiz Metin Dirimtekin deprem felaketiyle ilgili olarak basına bilgi verdi”, Bingöl, 8 Haziran 1971.

83 "Silahlı Kuvvetler 150 Bin Lira Verdi", Akşam, 25 Mayıs 1971.

84 "Tunç'un Demeci”, Akşam, 26 Mayıs 1971.

85 "Bingöl'de", Akşam, 27 Mayıs 1971.

86 "Ege'li işçilerin Bingöl'e yardımı 4 milyonu aşacak", Akşam, 30 Mayıs 1971.

87 “İstanbul'da Yardım Kampanyası", Milliyet, 26 Mayıs 1971.

88 “Deprem Bingöl'ü Viran Etti”, Bingöl, 31 Mayıs 1971.

89 "Türk-İş deprem için kampanya açtı", Akşam, 24 Mayıs 1971.

90 Türk-İş’in yardım kampanyasına yabancı sendikalar da katıldı”, Akşam, 10 Haziran 1971.

${ }^{91}$ Türkiye Cumhuriyeti Cumhurbaşkanlığı Devlet Arşivleri Başkanlı̆̆ı Cumhuriyet Arşivi (BCA), 030.18.1.2/268.48.18. (02.07.1971).

92 BCA, 030.18.1.2/273.77.5. (25.10.1971).

93 "Deprem bölgelerine yardım için", Dünya, 19 Haziran 1971.

${ }^{94}$ Adviye Fenik, “Afet Zammı”, Son Havadis, 20 Haziran 1971.
} 
Gaziantep'tir. ${ }^{95}$ Geçici olarak alınmış olan bu karar, Bingöl için ancak 20 Mayıs 1975 tarihinde yine Bakanlar Kurulu'nun kararıyla kaldırılabilmiştir. ${ }^{96}$

İçeriden gelen desteklerin yanı sıra dışarıdan da birçok manevi destek ve maddi yardım gelmiştir. Yabancı devletler deprem karşısında Türkiye'yi yalnız bırakmamıştır. 50 ülke Türkiye'ye taziye mesajlarını iletmiştir. ${ }^{97}$ Türkiye'nin sınır komşularından Yunanistan Kralı, Türkiye Cumhurbaşkanı Cevdet Sunay'a, "Yunan milleti ve şahsım adına, Bingöl ve Genç'te meydana gelen ve Türk milleti içinde pek çok can kaybına yol açan felaket münasebetiyle, Ekselanslarından en samimi taziyelerimi kabul buyurmaların rica ederim" mesajinı göndermiştir. ${ }^{98}$ Başta Türkiye'nin diğer sınır komşusu İran Şehinşahı Mohammad Reza Pahlavi ${ }^{99}$ olmak üzere ABD Başkanı Richard Nixon, ${ }^{100}$ Federal Almanya Cumhurbaşkanı Gustav M. Heinemann ${ }^{101}$ ve Çin Cumhurbaşkanı Chiang Kai-Shek ${ }^{102}$ de benzer mesajlar iletmiştir. Devlet liderlerinin yanı sira dini lider Papa 6. Paulus'tan gelen taziye mesaj1 ${ }^{103}$ da dikkatlerden kaçmamaktadır.

Yabancı ülkelerden taziye mesajının yanı sıra çok sayıda maddi yardım ve yardım teklifleri ulaşmıştır. Yunanistan Kızılhaçı doğrudan doğruya Türk Hava Yolları'nın Atina bürosu ile temasa geçerek depremde zarar görenlere ulaştırılmak üzere 34 ton tutarında, 1.700 kalem yardım malzemesi göndereceğini bildirmiş ve 10 tonluk ilk partiyi 26 Mayıs'ta yola çıkartmıştır. İlk partide çadır, battaniye ve konserve yer almıştır. ${ }^{104} 29$ Mayıs'ta da yine Yunan Kızılhaçı 25 ton tutarında çadır, battaniye ve çok miktarda ilacı İstanbul ve İzmir'e uçaklarla ulaştırmıştır. ${ }^{105}$ Avusturya Kızılhaçı da Kızılay'a teslim edilmek üzere uçakla 1.000 adet battaniye ve bir miktar ilaç göndermiştir. Ayrıca depremzedelerin diğer ihtiyaçlarını karşılamak için bir kampanya başlatılmıştır. Avusturya'da yaşayan Türk işçileri ve vatandaşları da aynı amaçlarla bir kampanya başlatmıştır. ${ }^{106}$ Viyana'da bulunan Siebenten-Tags-Adventisten ismindeki hayır kuruluşu Viyana'daki Türk Büyükelçiliği'ne müracaat ederek bir miktar nakdi bağışta bulunmuştur. ${ }^{107}$ İngiltere'deki bir hayır cemiyeti tarafından bağışlanan 400 adet çadır da bir İngiliz uçağı ile Malatya'ya sevk edilmiştir. ${ }^{108}$ Tunus'taki Türk Büyükelçiliği'nde çalışan Türklerin aralarında 300 dolar toplayarak postayla Türkiye'ye gönderdikleri para da önemli yer tutmuştur. ${ }^{109}$ Diğer yandan Brüksel'deki Türkiye Büyükelçiliği'nde çalışanlar da bağış hesabı açarak yardım toplamaya yoluna gitmişlerdir. İki tane yabancı yardım örgütü de Brüksel'deki Türk Büyükelçiliğii'ne başvurarak 2 ton yardım malzemesi göndereceklerini bildirmiştir. ${ }^{110}$

Federal Almanya Cumhuriyeti'nin de Türkiye'ye çeşitli yardımlarda bulunduğu görülmektedir. 26 Mayıs'ta Almanya'nın Diyarbakır'a 3 uçak ile yardım malzemesi göndereceği ifade edilmiştir. Malzemeler içerisinde çadır, 2 adet helikopter, battaniye, ilaç, su tasfiye cihazı

\footnotetext{
95 “9 İlde Grev ve Lokavt Yasaklandı”, Milliyet, 17 Temmuz 1971; BCA, 030.18.1.2/269.52.3. (20.05.1975).

${ }^{96}$ BCA, 030.18.1.2/269.52.3. (20.05.1975).

${ }^{97}$ Taziye mesaj1 gönderen ülkelerin isimleri için Bkz. CCSA, Yer No: 5/7-29, Fihrist No: 9412, s. 1-8.

${ }^{98}$ CCSA, Yer No: 5/7-29, Fihrist No: 9412-59.

${ }^{99}$ CCSA, Yer No: 5/7-29, Fihrist No: 9412-53.

${ }^{100}$ CCSA, Yer No: 5/7-29, Fihrist No: 9412-50.

${ }^{101}$ CCSA, Yer No: 5/7-29, Fihrist No: 9412-75.

${ }^{102}$ CCSA, Yer No: 5/7-29, Fihrist No: 9412-70.

${ }^{103}$ CCSA, Yer No: 5/7-29, Fihrist No: 9412-15.

${ }^{104}$ CCSA, Yer No: 5/7-29, Fihrist No: 9412-47.

105 “Dıș ve İç Yardımlar Devam Ediyor”, Dünya, 30 Mayıs 1971.

${ }^{106}$ CCSA, Yer No: 5/7-29, Fihrist No: 9413.

107 CCSA, Yer No: 5/7-29, Fihrist No: 9412-40.

108 “Bir İngiliz Uçağı Deprem Felaketzedeleri İçin Yardım Getiriyor”, Dünya, 30 Mayıs 1971.

${ }^{109}$ CCSA, Yer No: 5/7-29, Fihrist No: 9412-39.

110 CCSA, Yer No: 5/7-29, Fihrist No: 9412-42.
} 
ve jeneratör yer almaktadır. ${ }^{111} 26$ Mayıs'ta Alman Kızılhaç teşkilatına bağlı 15 araçlık konvoy Diyarbakır'dan Bingöl'e hareket etmiştir. Konvoyun içerisinde 8 kişilik bir ilk yardım ekibi de yer almıştır. ${ }^{112}$ Ayrıca Türkiye' deki Federal Almanya Büyükelçiliği depremzedelere harcanmak üzere 10 bin mark tutarında bir çek vermiştir. ${ }^{113}$ Amerika'dan da özel uçakla yardım malzemesi gönderilmiştir. $3.600 \mathrm{~kg}$ ağırlığındaki çadır, battaniye ve tıbbi malzemeden teşekkül yardım deprem bölgesine sevk edilmiştir. Ardından da 2 uçak içinde 10.000 battaniye, 1.000 çadır ve ilaç yola çıkarılmıştır. ${ }^{114}$

Türkiye'nin sınır komşusu İran; 400 çadır, 2.000 battaniye, 2 ton ilaç, 500 aile paketi, Hollanda 6.000 battaniye, 182 karton çocuk maması, Finlandiya; 70 çadır, 3.000 battaniye, İngiltere; 200 çadır, 2.000 battaniye, Avusturalya; 1.000 Avusturalya doları, Japonya; 2.000 dolar, Aİ; 1.000 çadır, 10.000 battaniye, bol miktarda antibiyotik ve pansuman malzemesi ve Avusturya 1.000 battaniye ve çeşitli ilaçlar göndermiştir. Yugoslavya, Bulgaristan, Norveç ve İsveç de yardım göndereceklerini bildirmiştir. ${ }^{15}$ Öte yandan İstanbul'da misafir bulunan Fransız Donanması Komutanı, İstanbul S1k1 Yönetim Komutanlığı'na bir mesaj göndererek depremde zarar görenlere yardıma hazır bulunduklarını bildirmiştir. Bu teklife Birinci Ordu ve S1kı Yönetim Komutanlığı teşekkür ederek cevap vermiştir. ${ }^{116}$

Dış ülkelerden yapılan bağışlar içerisinde en ilginç olanı Çin'in yaptığı 10 milyon tutarındaki bağıştır. Türkiye'nin Kıta Çin'i tanıma noktasında görüşmelerin devam ettiği sırada yapılan bu bağış bir iyi niyet göstergesi olarak kabul edilmiştir. ${ }^{117}$ Bu yardımdan sonra Türkiye Çin'i resmen tanımışıır. ${ }^{118}$

Dış ülkelerden depremzedelere şahsi yardımların da yapıldığı görülmektedir. 2. Dünya Savaşı sırasında Türkiye'nin Tokyo Büyükelçisi'nin komşusu olan ve Türkiye'ye hayranlık duyan bir Japon kadın Kızılay'a 3.000 dolarlık bir bağışta bulunmuştur. Bağışı, "Hem Türklere olan hayranlığl ve hem de kisa bir süre önce vefat eden kendisi gibi Türk dostu olan eşinin vasiyeti üzerine yaptığını" bildirmiştir. ${ }^{119}$ Kıbrıs'ta Türk kuruluşları arasında en aktif olanlardan birisi de Kıbrıs Türk Kadınlar Birliği’ydi. Bu birlik, Burdur ve Bingöl depremzedeleri yararına Lefkoşa'da bir balo düzenlemiştir. Baloda toplanan bağışların depremzedelere verileceği açıklanmıştır. ${ }^{120}$

Resmi verilere bakıldığında içeriden ve dışarıdan yapılan yardımların çok büyük olduğu görülmektedir. Acil yardım çalışmaları adı altında Bingöl Valiliği emrine 505.000 lira, Bingöl için diğer illerin emrine 105.000 lira ve Elazığ Valiliği emrine 187.500 lira verilmiştir. Toplamda bu miktar 797.500 lirayı bulmuştur. Barınma (çadır) anlamında ise İmar ve İskân Bakanlığı 2005, Sivil Savunma Örgütü 340, Kızılay Genel Başkanlığı 7.500 ve dış ülkeler de 3.932 çadırı depremzedelere tahsis etmiştir. Bu çadırların toplamı 13.777'dir. Bingöl'de havanın halen soğuk ve yağışlı olması nedeniyle battaniyeye ihtiyaç çok olmuştur. Bunu karşılamak için Kızılay Genel Başkanlığı 5.370 ve dış ülkeler 44.367 olmak üzere toplam 49.732 çadır bağışlamıştır. ${ }^{121}$ Bingöl

\footnotetext{
111 CCSA, Yer No: 5/7-29, Fihrist No: 9412-44; CCSA, Yer No: 5/7-29, Fihrist No: 9412-41.

112 “Alman Kızılhaç Yardım Ekibi Bingöl'e Hareket Etti”, Dünya, 27 Mayıs 1971.

113 "Diş Yardimlar Da Başladı”, Akşam, 25 Mayıs 1971.

114 "Yabancı Ülkelerden Yardım Geliyor", Milliyet, 26 Mayıs 1971.

115 “'Bingöl'de Can Kaybı 861'e Yükseldi”, Akşam, 26 Mayıs 1971; "Yardım Devam Ediyor”, Dünya, 26 Mayıs 1971; "Diş Yardımlar", Tercüman, 26 Mayıs 1971.

116 “Misafir Fransız Donanması Yardıma Hazır”, Akşam, 26 Mayıs 1971.

117 "Pekin Bingöl depremi için 10 milyon lira bağıșta bulundu", Milliyet, 29 Mayıs 1971.

118 “Kıta Çin'i resmen tanıdık”, Akşam, 6 Ağustos 1971.

119 “Bir Japon kadını Bingöl'e yardım etti”, Milliyet, 16 Haziran 1971.

120 "Burdur ve Bingöl İçin", Milliyet, 17 Temmuz 1971.

121 CCSA, Yer No: 5/9-12, Fihrist No: 9852-141.
} 
Valilisi Ahmet Tosun'un ifadesine göre, 25 Ağustos 1971 tarihi itibariyle 13 milyon değerinde depremzedelere çadır, battaniye, ilaç, giyecek ve gıda yardımı yapılmıştır. ${ }^{122}$ Resmi veriler depremzedeler için çok büyük yardımların yapıldığını açıklasa da depremzedeler bu yardımların kendilerine ulaşmadığından dert yanacaklardır.

Yapılan yardımların zamanında ve sağlıklı bir şekilde depremzedelere ulaşması anlamında ilk andan itibaren büyük sorunların yaşandığı görülmektedir. Bingöl Belediye Başkanı Faik Ertuğrul, formaliteler yüzünden mevcut çadır ve yiyeceklerin halka dağıtılmadığını iddia etmiş ve bu konuda Bingöl Valisi Metin Dirimtekin ile münakaşa etmiştir. ${ }^{123}$ Basında Faik Ertuğrul'un haklılığını ispatlayan yer yer haberler çıkmıştır. Milliyet Gazetesi, bazı kişilerin çeşitli yollardan ele geçirdikleri çadırları çevre illere götürerek sattıklarını iddia etmiştir. Bu iddiasına da 25 Mayıs akşamı Diyarbakır yolunda çadır yüklü bir arabanın bulunmasını ve sahiplerinin ele geçirilememesini örnek göstermiştir. Gazete en önemlisi de yiyecek yardımının tam anlamıyla yapılamadığını ve halkın açlığını kuru ekmek yiyerek gidermeye çalıştığını aktarmıştır. ${ }^{124}$ Bunların bir sonucu olarak Bingöl ve köylerinden yakın komşu illere doğru büyük bir göç başlamıştır. ${ }^{125}$ Depremden sonraki iki gün içerisinde özellikle Diyarbakır ve Elazığ'a 2 bin kişi eşyalarını katırlara ve develere yükleyerek göç etmiştir. ${ }^{126}$ Göçü yardımların eksikliğine ve düzensizliğine bağlayan Milliyet Gazetesi, köy muhtarlarıla bir röportaj gerçekleştirmiştir. Gökdere köyü muhtarı Ali Kaya ve Terbasan köyü muhtarı Mahmut Çelik köylerine çok az miktar ekmek geldiğini veyahut hiç gönderilmediğini, köylerde salgın hastalıkların başladığını ve herkesin açıkta yattığını belirtmiştir. Bu konudaki dilek ve şikâyetlerini duyurmak için Bingöl şehir merkezine gelen muhtarların Bingöl Valisi Metin Dirimtekin ile görüşmesine izin verilmemiştir. ${ }^{127}$ Depremden sonraki günlerde havanın yağışlı geçmesi nedeniyle halk, Bingöl meydanında toplanarak Bingöl Valisi Metin Dirimtekin'den ekmek yerine çadır istemiştir. Dirimtekin ise yaptığı açıklamada, "Halk bizden ekmek yerine çadır istemektedir. Bugün dört bin çadır daha Elazığ'a ulaşacaktır. Ayrıca Elazı̆̆'da her gün 75 çadır daha yaptırılarak Bingöl'e getirilecek ve hemen halka dağıtılacaktır. Sikıntımız iki üç gün içinde tamamen ortadan kalkacaktır" demiştir. ${ }^{128}$ Fakat Bingöl Belediye Başkanı Faik Ertuğrul'a göre, asıl sorun yardımların azlığı değil, bir koordinasyonun olmamasından kaynaklanmaktaydı. Bunun için Faik Ertuğrul 27 Mayıs 1971'de kendi başkanlığında çeşitli meslek gruplarından, 10 kişiden oluşan "Halk Komitesi" $n i$ kurmuştur. Deprem bölgesine gönderilen yardımların zamanında yerlerine ulaşmasını ve ihtiyaç sahiplerinin ellerine geçmesini sağlamak amaciyla kurulan komite, depremzedelerin şikâyet ve dileklerini de tespit edecek ve Bingöl'de deprem nedeniyle başlayan göçü önlemeye çalışacaktır. ${ }^{129}$ Anlaşılacağ üzere, depremden sonra depremzedeler için birçok yardım yapılmasına rağmen yardımları düzenli ve sağlıklı bir şekilde dağıtacak bir organizasyonun olmaması halkı perişan etmiş ve halkın bir kısmı da bölgeden göçe başlamıştır. Arama kurtarma çalışmalarında da yaşanan bu aksaklık ve organizasyonsuzluk da hatırlanırsa sorunun ne denli büyük olduğu net bir şekilde görülebilir. Bu tür sorunları ortadan kaldırmak

122 CCSA, Yer No: 5/9-12, Fihrist No: 9852-125. İmar ve İskân Bakanlığı'nın yaptığı açıklamaya göre, 18 Haziran 1971 tarihi itibariyle Bingöl ve Burdur Depremleri için toplanan yardımların miktarı 14 milyon lirayı geçmiştir. Bunun dışında birçok yabancı ülke de çadır, battaniye ve ilaç gibi ayni yardımlarda bulunmuştur. "Deprem bağışları 14 Milyonu geçti”, Milliyet, 26 Haziran 1971.

123 "Bingöl Belediye Başkanı: Formalite Yardımı Aksatıyor", Akşam, 25 Mayıs 1971.

124 "Çadırlar Satılıyor", Milliyet, 26 Mayıs 1971.

125 "Bingöl'den göç başladı", Bingöl, 31 Mayıs 1971.

126 "Gönderilen Yardımlar", Dünya, 26 Mayıs 1971.

127 "Göç", Milliyet, 26 Mayıs 1971. Depremden sonra bir tedbir olarak halka kolera aşısı yapmıştır. "Kolera aşısına başlandı”, Bingöl, 2 Haziran 1971.

128 "Bingöl'de halk ekmek yerine çadır istiyor", Akşam, 27 Mayıs 1971.

129 “Halk Komitesi Kuruldu”, Akşam, 28 Mayıs 1971; “Bingöl'e iç ve dış yardım”, Dünya, 28 Mayıs 1971. 
üzere kurulan Halk Komitesi’ne benzer bir yapı kısa bir süre sonra Nihat Erim Hükümeti tarafindan da kurulacaktır.

Halk Komitesi'nin kurulmuş olmasına rağmen halkın, deprem yardımlarının zamanında ve yeteri miktarda yerlerine ulaşması konusundaki şikâyetleri sona ermemiştir. Bu dönemde adeta halkın sözcülüğü görevini üstelenen yerel basının iddiasına göre, Bingöl'ün şehir merkezi ve köylerinde evleri zarar gören ve artçı sarsıntılar nedeniyle evlerine giremeyen vatandaşların hepsine çadır ulaştırılmamıştır. 1 Haziran 1971 tarihi itibariyle halen 9.000 aile çadırsızdır. Havaların soğuk ve yağışlı geçmesi nedeniyle açıkta kalan depremzedelerin hayatlarının tehlike içerisinde olduğu ifade edilerek yetkililer uyarılmıştır. ${ }^{130}$ Ayrıca yardımların yavaş dağıtıldığından şikâyetçi olunarak kısa ömürlü gıda maddelerinin daha dağıtılmadan depolarda çürüdüğü iddia edilmiştir. Havaların soğuk gitmesine rağmen yeteri miktarda battaniyenin dağıtılmayarak Elazı ̆̆’ daki depolara gönderilmesi de basın tarafından eleştirilmiştir. ${ }^{131}$ Bingöl Valisi Metin Dirimtekin, basına yaptığı açıklamada çadır ihtiyacının en kısa sürede tamamlanacağını belirtmiştir. ${ }^{132}$ Valinin açıklamasına ve depremin üzerinden 17 gün geçmiş olmasına rağmen 15 hanenin çadır alamayarak soğukta kalmaya devam ettiği İkbal Gazetesi tarafından öne sürülmüş̧ür. 52 kişinin öldüğü Burdur Depremi'nde Burdurlulara 14 bin çadır dağıtılırken iki bine yakın ölü veren Bingöl'de bu güne kadar neden 6 bin çadır dağıtıldığ 1 sorgulanmış ve Başbakan Nihat Erim'in verdiği sözü tutmadığı belirtilmiştir. Erim, üç gün içerisinde çadır ihtiyacının tamamlanacağını ifade etmesine rağmen gelinen noktada bu sözünü yerine getirmemiştir. ${ }^{133}$ Bingöl Gazetesi ise eleştirilerini daha üst seviyeye taşımış ve depremin üzerinden 21 gün geçmiş olmasına rağmen çadır ihtiyacı giderilemediği gibi yetkililer tarafından bu yönde hiçbir çalışmanın yapılmadığını aktarmıştır. ${ }^{134}$ Aynı zamanda gazete bazı mahallere hiç yardımın yapılmadığından söz ederek yardımların mahalle ve köylere eşit dağıtılmasını istemiştir. ${ }^{135}$

Bingöl için gönderilen iç ve dış yardımların diğer bir deprem bölgesi olan Burdur'a kaydırıldığını iddia eden İkbal Gazetesi, yetkililerden bu yardımların doğrudan doğruya Bingöl'e aktarılmasını talep etmiştir. ${ }^{136}$ Diğer yandan Burdurlu depremzedeler de kendilerinden ziyade en çok yardımın Bingöl'e yapıldığını ifade ederek Konya Milletvekili İhsan Kabadayı'ya dert yanmışlardır. ${ }^{137}$

Hükümetin Burdur'a Bingöl'den daha çok yardım yaptığına ilişkin iddialara İmar ve İskân Bakanı Selahattin Babüroğlu, Millet Meclisi kürsüsünden yanıt vermiştir. Babüroğlu, “...Bingöl ve Burdur zelzelelerinde, ne Bingöl'e daha fazla bir müsamahall yardim, ne de Burdur'al ihtiyacından fazla iltimasl yardım yapılmıştır. Her ikisi de aynı ölçüde, her ikisi de aynı biçimde, her ikisi de aynı ehemmiyette tutularak yardımlar götürülmüştür "'138 demek suretiyle yukarıdaki iddiaları reddederek tartışmalara cevap vermiştir.

Yukarıda ifade edilen şikâyetlerin yükselmesi üzerine Nihat Erim Hükümeti 17 Haziran 1971 tarihinde Burdur ve Bingöl depremleri dolayısıyla hükümetçe alınmış ve alınacak tedbirlerle yapılan iç ve dış yardım işlerinin düzenli, verimli ve hızlı bir şekilde yürütülebilmesi için "Afetler Merkez Koordinasyon Kurulu” isminde bir teşkilat kurmuştur. Başkanlığını İmar ve İskan

130 "Çadır ihtiyacı giderilemedi”, Bingöl, 1 Haziran 1971.

131 "Yardım tevziatı biraz daha hızlandırılmalıdı", Bingöl, 1 Haziran 1971.

132 "Sayın Valimiz Dirimtekin basına bilgi verdi”, Bingöl, 4 Haziran 1971.

133 "Bingöl'de 15 hane halen çadırsızdır", Ikbal, 10 Haziran 1971.

134 "Bugün Depremin 21 inci günü olduğu halde daha hiçbir çalışma yapılmamıştır”, Bingöl, 12 Haziran 1971.

135 "Deprem komitesi ve çalışmaları", Bingöl, 14 Haziran 1971.

136 "Bingöle yapılan iç ve dış yardım Burdura da kaydırılıyor", İkbal, 12 Haziran 1971.

${ }^{137}$ MMTD, D.3, C.14, T.2, B.114, s. 307. (16.06.1971).

138 MMTD, D.3, C.14, T.2, B.114, s. 308. (16.06.1971). 
Bakanlığı Müsteşarı’nın yapacağı bu kurulda Milli Savunma, İçişleri, Sağlık ve Sosyal Yardım, Çalışma, Köyişleri Bakanlıkları ile, Dışişleri Bakanlığı Birleşmiş Milletler Dairesi Genel Müdürü ve Genel Kurmay Başkanlığı'ndan yetkili bir temsilci yer alacaktır. Kızılay ise bu kurulun tabi üyesi olacaktır. Afetler Merkez Koordinasyon Kurulu, bundan sonra meydana gelecek olan deprem, yangın, su baskını gibi olağanüstü afet hallerinde de, Kurul Başkanının çağrısı ile, hemen toplanacaktır. Deprem bölgeleri valileri doğrudan doğruya bu kurul başkanıyla temas edecek, şikâyet ve ihtiyaçlarını en kısa yolla kurul başkanlığına bildirecektir. ${ }^{139}$ Bakıldığında Bingöl ve Burdur depreminde yaşanan aksaklık ve organizasyonsuzluklar böyle bir kurulun kurulmasını sağladığı ifade edilebilir. Dolayısıyla Bingöl Depremi, deprem öncesi ve sonrası alınması gerekli tedbirler anlamında hükümete önemli dersler vermiş ve hükümet de bu dersler doğrultusunda çeşitli düzenlemelere gitmiştir.

Afetler Merkez Koordinasyon Kurulu kurulmasına rağmen depremzedelerin şikâyet ve istekleri sona ermemiştir. Çadır sorunu, yardımların dengesizliği ve en önemlisi su problemi gündeme getirilmeye devam edilmiştir. ${ }^{140}$ Haziran ayında Bingöl'e gelerek incelemelerde bulunan Milli Güven Partisi'nden Konya Milletvekili İhsan Kabadayı da Millet Meclisi kürsüsünden Bingöl'de iş ve hizmetlerin bir perişanlık içerisinde yürütüldüğünü aktarmıştır. ${ }^{141}$ 22 Haziran 1971'de Bingöl Belediye Başkanı Faik Ertuğrul hükümetin dikkatini Bingöl'e çekmek için Ankara' ya gitmiş ve burada yaptığı basın toplantısında ilgisizlikten yakınarak halen 3 bin çadıra ihtiyaçlarının olduğunu kaydetmiştir. ${ }^{142}$

Yerel basın depremzedelerin sahipsiz bırakıldığı ve depremzedelerin sorunlarına ilgi gösterilmediği iddiasını her firsatta sürdürmeye devam etmiştir. Bingöl Valisi Metin Dirimtekin'in yerine atanan yeni Vali Ahmet Tosun'a da depremzedelerin sorunlarını anlatan yerel basın, yeni validen özellikle su sorununu çözmesini talep etmiştir. Su şebekesi, içme suyu da dahil olmak üzere yörenin ihtiyaçlarına cevap verebilecek durumda değildi. Yakında yapılacak inşaat çalışmalarında da suya büyük ihtiyaç duyulacak olması nedeniyle Vali Tosun, gerekeni yapacağı sözünü vermiştir. ${ }^{143}$ Su sorunu Bingöl'e gelip çalışmalarda bulunan Afet İşleri Genel Müdürü Erol Tuncer'e aktarılmış ve Tuncer, İller Bankası'nın yeni konutların yapıldığı yerlerde artezyen kuyularını açması suretiyle su sorunu halledileceği müjdesini vermiştir. ${ }^{144}$ Fakat Bingöl Milletvekili Sıddık Aydar'ın Meclis konuşmalarına bakılacak olunursa su sorunu Bingöl'de 1972 yılı itibariyle halen tam olarak çözülebilmiş değildir. ${ }^{145}$

Depremin alt üst ettiği Bingöl'ün birden fazla sorunu vardı. En büyük sorun Bingöl için yapılan yardımların halen depremzedelere ulaşmamış olmasıdır. ${ }^{146}$ Örneğin, Hollanda Bingöl'de kullanılmak üzere Türkiye'ye 2 adet ambulans gönderdiği halde bu ambulanslar Bingöl'e getirilmemiştir. Bu ambulansların ve diğer yardımların Bingöl'e ulaştırılmasını isteyen basın, hem Bingöl Valiliği'ne hem de hükümete seslenmiştir. ${ }^{147}$ Yine depremin üzerinden 2 ay

\footnotetext{
${ }^{139}$ CCSA, Yer No: 5/5-24, Fihrist No: 6537-4.

140 "Bazı Yardım Malzemesi Vatandaşa İletilmiyor”, İkbal, 15 Haziran 1971; "Biz Diyoruz Ki”, Bingöl, 18 Haziran 1971; "Şehrin su derdi ilgili mercilere iletildi”, İkbal, 22 Haziran 1971; “Şehir ve köylerdeki fark”, Bingöl, 23 Haziran 1971.

${ }^{141}$ MMTD, D.3, C.14, T.2, B.114, s. 306. (16.06.1971).

142 "B. Başkanımız Faik Ertuğrul dün Ankara'da basın toplantısı yaptı”, Bingöl, 23 Haziran 1971.

143 "İlimizin Su Derdi Çözümlenecek”, İkbal, 28 Haziran 1971.

144 “Şehirde su konusu giderilecektir”, Bingöl, 10 Temmuz 1971; "Şehir Suyu İ. Bankası tarafından takviye ediliyor”, Ikkbal, 21 Temmuz 1971.

${ }^{145}$ MMTD, D.3, C.22, T.3, B.49, s. 340. (25.02.1972).

146 A. Hikmet Yurtsever, “Bingölde Durum...”, İkbal, 16 Temmuz 1971.

147 A. Hikmet Yurtsever, "Neden olsun?”, Bingöl, 23 Temmuz 1971.
} 
geçmesine rağmen resmi daireler hizmetlerini çadırlarda vermeyi sürdürmekteydi. Bu durum ise hizmetlerin verimsiz olmasina neden oluyordu. ${ }^{148}$

Sözü edilen diğer büyük bir sorun ise depremden sonra ekonomik hayatı felce uğrayan Bingöl'ün işsizlik sorunuydu. Bingöllü işsiz gençler dururken yabanc1 işçiler şantiyelerde çalıştırılıyordu. $\mathrm{Bu}$ işsiz gençler ise depremden sonra ekonomik anlamda da zor durumda olduklarını ifade ederek işçi alımında kendilerine öncelik verilmesini yetkililerden sık sık talep etmekteydiler. ${ }^{149}$ Fakat gençlerin bu taleplerinin yerine getirilmediği görülmektedir. Örneğin, 40 kişilik bir öğrenci grubu iş başvurusu için Deprem İnşaat Amirliği'ne toplu halde gidince yanlış anlaşılmışlar ve öğrenciler polise şikâyet edilmiştir. Öğrencilerin emniyete götürülerek sorgulanması da tepkilere neden olmuştur. ${ }^{150}$

Depremzedelerin ekonomik sorunlarına çare bulmak adına Çalışma Bakanlığı yurt dışına gönderilecek işçi kontenjanında Bingöl'deki depremzedeler için özel bir artışa gitmişti. Ancak özel kontenjandan faydalanma bazı kısıtlayıcı şartlara bağlanmıştı. Depremden dolayı \% 80 hasar görmüş ve çiftçilikten başka mesleği olmayanlar bu özel kontenjanlara başvurabilecekti. Ancak Bingöllüler, çiftçilik mesleğini yapanların dışında diğer meslek erbaplarına da başvurabilme olanağının tanınması talebinde bulunmuşlardır. ${ }^{151}$ Bakanlıkça bu talepleri de yerine getirilmemiş ve İş ve İşçi Bulma Kurumu başvuruda bulunan binlerce kişi içerisinden 836 kişiyi hak sahibi olarak belirlenmiştir. ${ }^{152}$ Bingöl Cumhuriyet Senatörü Arif Hikmet Yurtsever'in 11 Kasım 1971 tarihinde Senato'da yaptığ 1 açıklamaya göre, bunların içerisinden sadece 10 kişi yurt dışına gönderilmiştir. ${ }^{153}$

Depremzedelerin önemli sorunlarından birisi de üniversiteye hazırlanan öğrencilerin durumuydu. Bingöllüler, özel kontenjanlar ayrılarak bu öğrencilerin üniversiteye sınavsız alınmasını hükümetten talep etmiştir. ${ }^{154}$ Milli Eğitim Bakanlığı da üniversiteye girecek öğrenciler için özel bir kontenjan ayırmayı uygun bulmuştur. ${ }^{155} 241$ Bingöllü depremzede öğrenci üniversiteye girmek için başvuruda bulunmasına rağmen birçok üniversite onlar için çok az kontenjan ayırmıştır. ${ }^{156}$

Depremden sonra Bingöl'de sağlik ve sosyal yönden de tedbirsizlik ve ilgisizlik görülmüştür. Basına göre, çevre temizliğine önem verilmeyerek Bingöl bir salgın hastalık tehlikesi ile yüz yüze getirilmiştir. Hal böyle iken doktorlar da izin, rapor, tayin ve vekil suretiyle şehri terk etme yoluna girmiştir. Sağlık Bakanlığı ve Bingöl Valiliği bu durum karşısında tedbir alacağına adeta bunlara kolaylık sağlamış ve halk bu duruma sert tepki göstermiştir. ${ }^{157} 1971$ yılının ağustos ayının sonuna gelinmiş olmasına rağmen Bingöl şehir merkezinde enkaz kaldırma çalışmalarının

\footnotetext{
148 A. Hikmet Yurtsever, “ Bingölde Durum...”, İkbal, 16 Temmuz 1971; Hüsnü Mollaoğlu, "Sonu ne olacak?”, Bingöl, 17 Temmuz 1971; A. Hikmet Yurtsever, "Çadır altında hizmet”, İkbal, 1 Temmuz 1971.

149 Hüsnü Mollaoğlu, “Sonu ne olacak?”, Bingöl, 17 Temmuz 1971; “Sayın Valimizden Bingölümüzün az da olsa dilek ve temenniler", Bingöl, 25 Haziran 1971.

150 "Dün bir grup öğrenci işe alınmak üzere inşaat amirliğine başvurdu”, Bingöl, 24 Temmuz 1971; "İş arayan afetzede öğrenciler Emniyete götürüldü”, İkbal, 24 Temmuz 1971.

151 "Yurt dışına gönderilecek işçiler için çiftçi olma şartının kaldırılması istendi", İkbal, 14 Temmuz 1971.

152 "Yurt dışına işçi müracaatları devam ediyor", İkbal, 23 Temmuz 1971; "Yurt dışına gidecek 836 kişi tespit edildi", Bingöl, 2 Eylül 1971.

${ }^{153}$ Cumhuriyet Senatosu Tutanak Dergisi (CSTD), C.1, T.11, B.3, s. 30. (11.11.1971).

154 "Hükümetimizden neler bekliyoruz", Ikkbal, 10 Haziran 1971.

155 “Üniversiteye Girecek Bingöllü Öğrencilere Özel Kontenjan Tanındı”, İkbal, 10 Temmuz 1971.

156 "Bingöllü Üniversite öğrencileri için imkânlar aranıyor”, Bingöl, 6 Ağustos 1971.

${ }^{157}$ A. Hikmet Yurtsever, "Yeni Valimiz Göreve Başlarken”, İkbal, 24 Haziran 1971; A. Hikmet Yurtsever, "Bingölde Durum...”, İkbal, 16 Temmuz 1971; Hüsnü Mollaoğlu, "Sonu ne olacak?”, Bingöl, 17 Temmuz 1971.
} 
henüz tamamlamamış olması ${ }^{158}$ göz önünde bulundurulacak olunursa halk sağlığının ne denli tehlikede olduğu daha rahat anlaşılabilir.

Yukarıdaki sorunların temel nedeni deprem sonrası Bingöl'de yürütülen plansız, programsız ve disiplinsiz çalıșmalardı. Belli bir süre sonra sorunların çözülmesi anlamında ümidini kaybeden halk Bingöl'den göçü hızlandırmıştır. ${ }^{159}$ Şehir merkez nüfusunun 17.000 civarında olduğu Bingöl'de depremden hemen sonra yaklaşık 2.000 kişinin çevre illere göç etmesi ${ }^{160}$ geride kalan halkın moraliniz bozmuş ve göç sorunu halk tarafından sürekli getirilen bir konu haline gelmiştir. ${ }^{161}$ Halkın yanı sıra Bingöl'de görev yapan memurlar da tayinlerini başka bir ile çıkartmanın peşine düşerek ${ }^{162}$ göç edenlerin sayısını artırmıştır. Doktorların yanı sıra din adamlarının da tayin yoluyla Bingöl'den göç etmeye çalı̧̧ması depremzedelerin büyük tepkisine neden olmuştur. Bingöl şehir merkezinde görev yapan bütün din adamları depremden bir ay sonra tayinlerini başka illere çıkartmışlardır. Böylece şehir merkezinde görev yapacak hiçbir din adamı kalmamıştır. $\mathrm{Bu}$ din adamları önceki yıllarda tayinleri çıktığ 1 halde ne yapıp edip tayinlerini durdurmuştu. Deprem nedeniyle tayin istemelerini depremzedeler şu sert sözlerle eleştirmiştir: “...Halkın yanında ve halkla beraber oldukların söyleyen sayın hocalarımı deprem felaketinden sonraki gidişleri ile halkın yanında olmadıklarını ispatlamış oldular. Dar günün adamı az bulunur dememişler mi?...Temenni ederiz ki Diyanet İşleri Başkanlığı alınmış bulunan kadrolart iade ile gerçekte halkın yanında olabilecek ve ona manevi desteği verebilecek yeni din adamların ilimize tayin etsin. Etsinler ki gidenler gidişlerine mazeret arayamasınlar". ${ }^{63}$

Depremden sonra Bingöl'e sahip çıkılmadığından ve deprem sonrası her türlü çalışmanın aksak yürütüldüğünden sürekli dert yanan yerel basın, bu konuda merkezi hükümeti ve deprem komitesini eleştirmenin yanı sıra Bingöllü siyasetçileri de eleştirmiştir. 27 Temmuz 1971'de Bingöl'e gelip incelemelerde bulunan AP Bingöl Milletvekili Mehmet Bilgin'e halk da sert tepki göstermiştir. Deprem sonrasında Bingöl milletvekillerinin kendilerini sahipsiz bıraktıkları yolundaki siteme Mehmet Bilgin, Bingöl için Meclis'te çalıştıklarını iddia etmiş ve ardından bunu Meclis zabıtlarını göstererek ispat edebileceğini kaydetmiştir. Halk da Meclis’te Bilgin'in depremin hemen ardından ufak birkaç konuşma yaptığını, ancak bu konuşmaların Bingöl'ün esas meseleleriyle ilgili olmadığını aktarmıştır. Devamında halk, Bilgin'e Hollanda'dan Bingöl için gönderilen iki ambulansın Ankara'da alıkonulmasına karşı harekete geçip geçmediğini, öğrenciler için sınavsız özel kontenjan ayrılması anlamında çalışma yapıp yapmadığını, hasar tespitindeki usulsüzlere müdahale edip etmediğini ve en önemlisi de Bingöl için özel bir kanun hazırlayıp Meclis'e sunup sunmadığını sormuştur. Bilgin ise tepkiler karşısında kendilerinin imkânlar ölçüsünde çalışma yaptıklarını ve bu şikâyetleri Meclis'e taşıyacağını ifade etmiştir. ${ }^{164}$ Millet Meclisi tutanaklarına bakıldığında AP Bingöl Milletvekili Mehmet Bilgin'in 27 Temmuz 1971'den önce Meclis'te depremle ilgili konuşma yapmadığ 1 görülmektedir. Fakat Bilgin'in partisi AP, depremden hemen sonra Bingöl'e incelemeler yapmak üzere üç kişiden oluşan bir

158 "Enkaz kaldırma işlemi devam ediyor", İkbal, 25 Ağustos 1971; "Bingöl'de henüz enkaz temizlenmedi”, Dünya, 30 Temmuz 1971. Basın, enkaz kaldırma çalışmalarının ağustos ayının sonuna gelinmiş olunmasına rağmen halen tam anlamıyla kaldırılmadığını iddia etse de resmi veriler bunun öyle olmadığını söylemektedir. Resmi kayıtlara göre, enkaz kaldırma çalışmaları 30 Haziran 1971 tarihinde tamamlanmıştır. CCSA, Yer No: 5/9-12, Fihrist No: 9852-140. 159 A. Hikmet Yurtsever, "Yeni Valimiz Göreve Başlarken", İkbal, 24 Haziran 1971.

160 “Bingöl'de can kaybı sayısı 861'e yükseldi”, Akşam, 26 Mayıs 1971; "Enkazların altı cesetlerle dolu”, Günaydın, 24 Mayıs 1971.

${ }^{161}$ Hüsnü Mollaoğlu, “Sonu ne olacak?”, Bingöl, 17 Temmuz 1971.

162 A. Hikmet Yurtsever, "Memur ve Bingöl”, Bingöl, 24 Haziran 1971.

163 "Bingöl'den göç devam ediyor", Bingöl, 28 Haziran 1971.

164 "Milletvekilimiz Mehmet Bilgin Bingöl için çalıştık dedi”, Bingöl, 29 Temmuz 1971. 
heyet göndermişti. ${ }^{165}$ Hükümete yardımcı olmak üzere incelemelerini bir rapora dönüştüren heyet, raporunu hükümete teslim etmiştir. ${ }^{166}$

Öte yandan AP Bingöl Milletvekili Mehmet Bilgin, Bingöl ziyaretinden sonra Ankara'ya dönünce 30 Temmuz 1971'de Millet Meclisi'nde gündem dıșı söz alarak depremzedelerin kendisine ilettiği şikâyet ve istekleri dile getirmiştir. Buna göre, Bilgin, Bingöl'de en büyük sorunun inşaat yapımı ve içme suyu sorunun olduğunu dile getirmiştir. Öğrencilerin eğitimi ile ilgili sözler verilmiş olunmasına rağmen bu yönde kesin adımların atılmadığını aktarmıştır. Bingöllü tüccar ve esnafın kredi borçlarının ertelenmesini isteyen Bilgin, kış gelmeden önce konutların yapılarak depremzedelerin konutlara yerleştirilmesini hükümetten rica etmiştir. Bunların yanı sıra Bilgin'in, Bingöl'de yaptığı başarılı yol yapım çalışmalarından dolayı hükümeti takdir ettiği de görülmektedir. ${ }^{167}$ Bingöl Milletvekili Mehmet Bilgin'in 1972 yılında depremzedelerin sorunlarını Millet Meclisi'nde daha sıkı savunduğu söylenebilir. ${ }^{168}$

Başbakan Nihat Erim'in 1971 yılının ağustos ayında Bingöl'e gelerek depremzedelerin dertlerini dinleyeceğini ifade etmesine rağmen Bingöl'e gelmekten vazgeçmesi depremzedelerin büyük tepkisine neden olmuş ve Erim sözünü tutmamakla eleştirilmiştir. Bununla birlikte depremzedeler iyice sahipsiz bırakıldığını düşünerek büyük bir umutsuzluk içerisine düşmüşlerdir. ${ }^{169}$ Erim, Bingöl'e gelmeyince Bingöl'den bir heyet oluşturulmuş ve depremzedelerin sorunlarını anlatmak üzere Ankara'ya gelerek Erim ile görüşmeye karar verilmiştir. ${ }^{170}$

\section{Depremzedelerin İskânında ve Yeniden İmar Faaliyetlerinde Yaşanan Sorunlar}

Kurtarma ve yardım çalışmalarında yaşanan aksaklıklar ve organizasyon eksikliği kendisini depremzedelerin iskânında ve şehrin yeniden imar faaliyetlerinde de gösterdiği görülmektedir.

Depremden sonra Bingöl'e ikinci gelişinde İmar ve İskân Bakanı Selahattin Babüroğlu kış gelmeden konutların yapılarak depremzedelerin açıkta kalmasının önleneceğini açıklamıştı. ${ }^{171}$ Konutların yapımı için ihaleye çıkılmış ve Ankara İmar Limited şirketi ihaleyi kazanmıştır. ${ }^{172}$ Şirket de, Başbakan Nihat Erim'e 25 Kasım 1971 tarihine kadar bütün konutların yapılacağı sözünü vermiştir. ${ }^{173}$ Fakat şirketin fiilen inşaatlara başlaması bir hayli uzamıştır. Bu durum depremzedeler üzerinde kış gelmeden inşaatların tamamlanamayacağı, dolayısıyla açıkta kalacakları endişesini doğurmuştur. ${ }^{174} \mathrm{Bu}$ endişe karşısında Afet İşleri Genel Müdürü Erol Tuncer ve İmar ve İskân Bakanı Babüroğlu'nun kıştan evvel konut yapımının tamamlanacağını açıklamasına ${ }^{175}$ rağmen halkın endişeleri sona ermemiştir. ${ }^{176}$ Çünkü ağustos ayının sonlarınal gelinmesine rağmen enkaz kaldırma çalışmaları tamamlanmadığı gibi fiili olarak inşaat

\footnotetext{
165 “AP Üç Kişilik Heyet Deprem Bölgesine Yolladı”, Dünya, 24 Mayıs 1971.

166 "Bingöl'e giden AP heyeti raporunu hükümete verecek", Dünya, 31 Mayıs 1971; MMTD, D.3, C.22, T.3, B.49, s. 303. (25.02.1972).

${ }^{167}$ MMTD, D.3, C.16, T.2, B.140, s. 264-265. (30.07.1971).

${ }^{168}$ MMTD, D.3, C.22, T.3, B.49, s. 344-348. (25.02.1972).

169 A. Hikmet Yurtsever, "Başbakan neden gelmedi", Bingöl, 16 Ağustos 1971; Zeki Atsız, "Başbakan gelmeyecek!...”, İkbal, 16 Ağustos 1971.

170 “Erim, gidemedi ama Bingöl'lüler Erim'e gelecek”, Milliyet, 15 Ağustos 1971.

171 "İmar İskân Bakanı Babüroğlu Bingölde tetkiklerde bulundu”, Bingöl, 7 Haziran 1971.

172 CCSA, Yer No: 5/9-12, Fihrist No: 9852-134.

${ }^{173}$ CSTD, C.1, T.11, B.3, s. 29 (11.11.1971).

174 Zeki Atsız, "Vadedilenlerin yapılacağı yok", İkbal, 19 Ağustos 1971; A. Hikmet Yurtsever, "Hoş Geldiniz Sayın Tuncer", İkbal, 6 Temmuz 1971.

175 "Hasar tespitleri yeniden yapılacak”, İkbal, 8 Temmuz 1971; "Babüroğlu deprem çalışmalarını izledi”, Bingöl, 4 Ağustos 1971.

176 A. Hikmet Yurtsever, "Bingöl'de durum”, İkbal, 16 Temmuz 1971.
} 
faaliyetlerine de başlanamamıştır. Hem yerel basına hem de Cumhuriyet Senatörü Arif Hikmet Yurtsever'e göre, bunun sebebi çalışanlar üzerinde sıkı bir kontrol mekanizmasının olmaması, kurumlar arası iletişim ve organizasyon eksikliğidir. ${ }^{177}$

Konutların kıştan evvel bitirilemeyeceği endişesinin yanı sıra depremzedelerde konut tipi konusunda bir takım endişeler de mevcuttu. Buna göre ahşap ve tuğla gibi konut tiplerinin yanında prefabrik konutların da yapılacağı İmar ve İskân Bakanlığı tarafından açıklanmıştı. ${ }^{178}$ Fakat depremzedeler prefabrik tipi konutların yapımına karşı çıkmışlardır. Depremzedelere göre, bu konut tipleri Bingöl'ün çetin soğuk kış şartlarına uymadığı gibi şehrin estetiğini de bozacaktır. ${ }^{179}$ Resmi kurumlara istekleri belirtmelerine rağmen hükümet, prefabrik konut tipinden vazgeçmemiştir. ${ }^{180}$

Bingöl'ün köylerinde konut yapımında daha çok ahşap karkas konut tipi tercih edilmiştir. Bunu sırasıyla ahşap ve beton prefabrik konut tipleri takip etmiştir. Bingöl şehir merkezinde ise daha çok 3 katlı karkas konut tipi tercih edilmiştir. İkinci ve üçüncü sırada da tercih edilen konut tipleri beton prefabrik ve tek katlı tuğladır. ${ }^{181}$ Dolayısıyla depremin Bingöl'ün mimari yapısını belli bir oranda değiştirdiği söylenebilir.

$\mathrm{Bu}$ süreçte depremzedelerin resmi kurumlara yaptıkları en büyük şikâyet, konutların belediye ya da hazine arsaları değil de şahıs arsaları üzerine yapılacak olmasıdır. Konutların şahıs arsaları üzerine yapılması halinde arsaların istimlak bedelinden dolayı konutları maliyeti artacak ve bu maliyet depremzedelere yüklenecekti. Maddi gücü yeterli olmayan halk, bu duruma tepki göstererek dikkatleri bu yöne çekmeye çalışmıştır. ${ }^{182}$ Şikâyetlerin artması üzerine Bingöl Valisi Ahmet Tosun da belediye ve hazine arsaları dururken şahıs arsalarına deprem konutlarının yapılmasına kendisinin de karşı olduğunu, ancak yetkinin kendisine ait olmadığını ifade etmiştir. Yetkililerin yapacağı jeolojik incelemeler sonucunda konutların nereye yapılacağına karar verileceğini aktarmıştır. ${ }^{183}$

Depremzedelerin yakındıkları bir diğer husus da hasar tespit elemanlarının hasar tespitleri yanlış yapmalarıdır. Ağır hasarlı binaların az ya da orta hasarlı olarak gösterilmesi nedeniyle depremzedeler açıkta kalma endişesini yaşayarak ${ }^{184}$ bu durumu İmar ve İskân Bakanı Selahattin Babüroğlu'na anlatmışlardır. Bakan da bariz şekilde yapılan hataların düzeltilmesi için İnşaat Amirliği’ne talimat verdiğini, ancak hasar tespitinin yeniden yapılmasının maddeten mümkün olmadığını kaydetmiştir. ${ }^{185}$ Bakanın emrine rağmen İnşaat Amirliği tarafından bariz şekilde yapılan hasar tespit hataları düzeltilmemiştir. Bu durum karşısında Cumhuriyet Senatörü Arif

\footnotetext{
177 A. Hikmet Yurtsever, "Bingöl'de durum”, Ikkbal, 16 Temmuz 1971; A. Hikmet Yurtsever, "Bingöl'de durum”, Bingöl, 20 Ağustos 1971; “380 adet prefabrike konutun yer teslimi henüz yapılmadı”, İkbal, 21 Ağustos 1971. Resmi kayıtlara göre, fiili olarak inşaat çalışmalarına 27 Temmuz 1971 tarihinde başlanmıştır. CCSA, Yer No: 5/9-12, Fihrist No: $9852-134$.

178 CCSA, Yer No: 5/9-12, Fihrist No: 9852-136; "İmar İskan Bakanı Babüroğlu Bingölde 6900 adet konut yapılacağını söyledi”, İkbal, 19 Haziran 1971.

179 "Bingölde Prefabrike konut yapılması kesinleşti", İkbal, 14 Haziran 1971; "Prefabrike Konutlara Karşı Tepki Arttı", İkbal, 16 Haziran 1971; "Hükümetimizden neler bekliyoruz", İkbal, 10 Haziran 1971.

180 "Bingölde Prefabrike konut yapılması kesinleşti”, İkbal, 14 Haziran 1971.

${ }^{181}$ CCSA, Yer No: 5/9-12, Fihrist No: 9852-136.

182 "Dereikasaran Sakinleri Dün Valiliğe 300 İmzalı Dilekçeyle Başvurdu”, İkbal, 29 Haziran 1971; A. Hikmet Yurtsever, "Hoş geldiniz Sayın Tuncer", Ikbal, 6 Temmuz 1971.

183 "Valimiz Sayın Ahmet Tosun...", Ikbal, 5 Temmuz 1971.

184 A. Hikmet Yurtsever, "Böyle olmaz Sayın Bakanım”, İkbal, 29 Haziran 1971.

185 "Babüroğlu deprem çalışmalarını izledi”, Bingöl, 4 ağustos 1971.
} 
Hikmet Yurtsever, Bakanın sözünün yerine getirilememesinden dolayı İnşaat Amiri Naci Belirgin'i suçlamıştır. Ona göre, Belirgin bu işi önemsememektedir. ${ }^{186}$

Bu arada 1971 yılının ağustos ayının sonu itibariyle Bingöl şehir merkezi elektrik şebekesi 3 milyon lira harcanarak tamamlanmıştır. ${ }^{187}$ Yine depremde zarar gören Bingöl şehir merkezi kanalizasyonu 15 milyon lira harcanarak ve 75.600 metre künk döşenerek bitirilmiştir. ${ }^{188}$ Resmi verilere göre, Bingöl merkez içme suyu şebekesinin 7 milyon 500 bin lira sarf edilerek tamamlandığı iddia edilse ${ }^{189}$ de aslında su şebekesi ya da içme suyu sorunu bu dönemde tam olarak çözülememiş, yarım bırakılmıştır. Cumhuriyet Senatörü Arif Hikmet Yurtsever, Senato'da bunu sık sık dile getirecektir. İmar ve İskân Bakanı Selahattin Babüroğlu ise Bingöl'ün içme suyunun şu an için çok acil olmadığını ifade ederek Yurtsever'in eleştiri ve şikâyetlerine cevap vermiştir. Babüroğlu'na göre, Bingöl'ün hemen halledilmesi gereken acil içme suyu sorunu yoktur. ${ }^{190}$

Depremzedelerin, konutların kış mevsiminden önce yetiştirilemeyeceği yönündeki endişelerinde ne kadar haklı oldukları ortaya çıkmıştır. 11 Kasım 1971 tarihinde İmar ve İskân Bakanı Selahattin Babüroğlu'nun Arif Hikmet Yurtsever'in sorusu üzerine verdiği cevaba göre, deprem bölgesinde bütün konutların yapımı tamamlanamamıştır. 139 köyde konut yapımına başlanmış ve bu köylerden 51 tanesinde konutlar tamamen bitmiştir. Diğerleri ise montaj halinde ya da halen yapım aşamasındadır. Şehir merkezinde ise 335 prefabrike konut tamamlanmıştır. 30 Kasım 1971 itibariyle de bu sayısı 745 konuta ulaşacaktır. Yapımı biten tek katlı 204 konut yine 30 Kasım'da 242'ye çıkacaktır. Üç katlı konutlarda 30 daire bitmiştir. Bu, 30 Kasım'da 360 daireye yükselecektir. Bakan Babüroğlu, konutların zamanında yetiştirilemediği eleştirisi karşısında bütün bu işlerin 105 gün işgünü içerisinde bitirildiğini aktararak bunun olağanüstü tedbirlerle başarıldığını aktarmıştır. 1972 yılında ise yarım kalan işlerin tamamlanacağını ifade etmiştir. ${ }^{191}$

İmar ve İskân Bakanlığı'nın 27 Aralık 1971 tarihinde deprem bölgesinde açıkta yani çadırlarda hiç kimsenin kalmadığını açıklamas ${ }^{192}$ Bingöl Milletvekili Mehmet Sıddık Aydar'ın tepkisine neden olmuştur. Aydar, eksi 40 derecede elbette ki hiç kimsenin dişarıda kalamayacağını, dolayısıyla evsiz olanların akrabalarının evlerine yerleştiğini belirtmiştir. Bunun da artık hiç kimsenin çadırda kalmadığı yani herkesin konut sahibi olduğu anlamına gelmeyeceğini aktarmıştır. ${ }^{193} 25$ Şubat 1972 tarihi itibariyle de İmar ve İskân Bakanı Serbülent Bingöl'ün açıklamalarına göre, deprem bölgesindeki meskenlerin merkezde \%38'i, köylerde ise \% 82'si tamamlanmıştır. ${ }^{94}$ Demokratik Parti Kütahya Milletvekili Mehmet Ersoy'a göre, depremden sonra yaşanan eksiklik ve aksaklıklardan dolayı sadece İmar ve İskân Bakanlığı'nı eleştirmek insafsızlı olacaktır. Asıl eleştirilecek olan şey, mevzuattaki boşluklar ve organizasyon eksikliğidir. Türkiye'de son yıllarda yaşanan depremlerde bir organizasyon eksikliği ve mevzuat boşluğu olduğunu görülmüştür. ${ }^{195}$ Zaten Ersoy'un dikkat çektiği hususta ne kadar haklı olduğu Bingöl Depremi’nde kanıtlanmıştır. Hükümet de bundan ders çıkararak daha

\footnotetext{
${ }^{186}$ A. Hikmet Yurtsever, "Hangisi Gerçek?”, Bingöl, 21 Ağustos 1971.

${ }^{187}$ CCSA, Yer No: 5/9-12, Fihrist No: 9852-162.

188 CCSA, Yer No: 5/9-12, Fihrist No: 9852-163.

${ }^{189}$ CCSA, Yer No: 5/9-12, Fihrist No: 9852-164.

${ }^{190}$ CSTD, C.1, T.11, B.3, s. 29-30. (11.11.1971); CSTD, C.2, T.11, B.28, s. 431. (04.02.1972).

${ }^{191}$ CSTD, C.1, T.11, B.3, s. 28-32. (11.11.1971).

192 MMTD, D.3, C.22, T.3, B.49, s. 328 (25.02.1972).

${ }_{193}$ MMTD, D.3, C.22, T.3, B.49, s. 338 (25.02.1972).

${ }^{194}$ MMTD, D.3, C.22, T.3, B.49, s. 327-328 (25.02.1972).

195 MMTD, D.3, C.22, T.3, B.49, s. 314-317 (25.02.1972).
} 
sonra meydana gelmesi muhtemel deprem gibi afetlere hazırlık için çalışmalar yapma yoluna gitmiştir.

İmar çalışmalarının ne zaman tamamlandığı tam olarak bilinmemekle birlikte 28 Mart 1978 tarihinde İmar ve İskân Bakanı Ahmet Karaaslan'ın Cumhuriyet Senatosu'nda verdiği bilgilere göre, Bingöl'deki imar çalışmaları tamamlanmıştır. Deprem bölgesinde 5.733 aile hak sahibi olarak tespit edilmiştir. Borçlanan 5.008 hak sahibi aileye karşılık 5.498 mesken yapımı, 1.141 de ahır ve samanlık yapımı tamamlanmıştır. Köylerden Bingöl şehir merkezine 333 aile nakledilmiş, 1961 mesken Bingöl şehir merkezinde, 3.537 mesken de merkez köyleriyle ilçe köylerinde yapılmıştır. Daimi iskân için harcamanın tutarı ise 260.002.100.53 liradır. ${ }^{196}$

\section{Sonuc}

22 Mayıs 1971 Bingöl Depremi'nin Burdur Depremi'nin hemen ardından ve 12 Mart Dönemi'nde meydana gelmesi Türkiye için büyük bir şok etkisi yaratmıştır. 1971 Bingöl Depremi bıraktı̆̆ 1 hasar ve zayiat açısından da diğer Bingöl depremlerinden ayrılmaktadır. Bu deprem, Bingöl'de çok büyük bir tahribata neden olduğu için şehir neredeyse yeniden inşaa edilmek zorunda kalınmıştır.

Depremin neden bu denli büyük bir hasara yol açtığını araştıran hükümet, bir takım önemli sonuçlara ulaşmıştır. Buna göre, Türkiye Deprem Bölgeleri Haritası yanlıştır. Bingöl gibi birinci derece deprem bölgeleri ikinci derece deprem bölgesi olarak gösterilmiştir. En önemlisi de deprem yönetmeliği yetersizdir. Bu nedenlerden dolayı binalardaki inşaat malzemeleri deprem riski ve bulunulan jeolojik yapıya göre kullanılmamıştır. Bingöl'de ise resmi binalar da dahil olmak üzere neredeyse bütün binalar kerpiçten yapılmış ve en önemlisi de deprem yönetmeliğine aykırı hareket edilmiştir. Bu tespitlerden sonra hükümet, 1972 yılında yeni bir Deprem Bölgesi Haritası hazırlayarak Bingöl'ü birinci derece deprem bölgesi ilan etmiştir. Yıkılan binalardan dolay1 müttehitler de sorumlu tutularak müteahhitlik müessesinin 1slah edilmesine karar verilmiştir. Yani hükümet, 1971 Bingöl Depremi'nden ders alarak bundan sonra meydana gelmesi muhtemel depremler için tedbirler alma yoluna gitmiştir.

Bingöl depremi içeride ve dışarıda çok büyük bir yankı uyandırmıştır. Depremzedelere çok büyük yardımlar yapılmasına rağmen gelen yardımlar, zamanında, eksiksiz, dengeli ve sağlıklı bir şekilde dağıtılamamıştır. Bu durum başta organizasyon eksikliği olmak üzere mevzuattaki boşluklardan kaynaklandığı için tedbir olarak hem Bingöl Belediyesi hem de hükümet deprem sonrası çalışmaları sağlıklı bir şekilde yürütecek yeni teşkilatlar kurmuştur. Bu yeni teşkilatlara rağmen de yardımların dağıtımı ve şehrin yeniden kurulması noktasında aksaklıklar sonlanmamış, dolayısıyla depremzedelerin şikâyetleri de sona ermemiştir. Kısacası 1971 Bingöl Depremi'nde çok başarılı bir afet yönetiminin sergilendiği söylenemez.

Yıkılan şehrin yeniden imarı ve iskânı konusunda da birçok sorunların yaşandığı söylenebilir. Depremzedelerin en çok şikâyet ettiği konular; içme suyu, hasar tespitteki yanlışlıklar, konutların şahıs arsalarına yapılması, konut yapımının yavaş yürütülmesi, siyasetçilerin kendilerini sahipsiz bırakması, sağlık, eğitim ve işsizlik şeklindedir. Yine depremzedelerin bu sorunlar karşısındaki çeşitli şikâyetlerine rağmen birçok sorun düzeltilmemiş ve çözümü zamana bırakılmıştır.

${ }^{196}$ CSTD, C.37, T.17, B.42, s. 184. (28.03.1978). 


\section{Kaynakça}

\section{Arşiv Belgeleri}

\section{T.C. Cumhurbaşkanlığı Cevdet Sunay Arşivi (CCSA)}

CCSA, Yer No: 5/5-24, Fihrist No: 6537-4.

CCSA, Yer No: 5/5-27, Fihrist No: 7058.

CCSA, Yer No: 5/5-27, Fihrist No: 7036.

CCSA, Yer No: 5/7-29, Fihrist No: 9412.

CCSA, Yer No: 5/7-29, Fihrist No: 9412-59.

CCSA, Yer No: 5/7-29, Fihrist No: 9412-53.

CCSA, Yer No: 5/7-29, Fihrist No: 9412-50.

CCSA, Yer No: 5/7-29, Fihrist No: 9412-75.

CCSA, Yer No: 5/7-29, Fihrist No: 9412-70.

CCSA, Yer No: 5/7-29, Fihrist No: 9412-15.

CCSA, Yer No: 5/7-29, Fihrist No: 9412-47.

CCSA, Yer No: 5/7-29, Fihrist No: 9413.

CCSA, Yer No: 5/7-29, Fihrist No: 9412-40.

CCSA, Yer No: 5/7-29, Fihrist No: 9412-39.

CCSA, Yer No: 5/7-29, Fihrist No: 9412-42.

CCSA, Yer No: 5/7-29, Fihrist No: 9412-44.

CCSA, Yer No: 5/7-29, Fihrist No: 9412-41.

CCSA, Yer No: 5/9-12, Fihrist No: 9852-139.

CCSA, Yer No: 5/9-12, Fihrist No: 9852-126.

CCSA, Yer No: 5/9-12, Fihrist No: 9852-124.

CCSA, Yer No: 5/9-12, Fihrist No: 9852-125.

CCSA, Yer No: 5/9-12, Fihrist No: 9852-141.

CCSA, Yer No: 5/9-12, Fihrist No: 9852-125.

CCSA, Yer No: 5/9-12, Fihrist No: 9852-140.

CCSA, Yer No: 5/9-12, Fihrist No: 9852-134.

CCSA, Yer No: 5/9-12, Fihrist No: 9852-136.

CCSA, Yer No: 5/9-12, Fihrist No: 9852-162.

CCSA, Yer No: 5/9-12, Fihrist No: 9852-163.

CCSA, Yer No: 5/9-12, Fihrist No: 9852-164. 
T.C. Cumhurbaşkanlı̆̆ı Devlet Arşivleri Başkanlığı Cumhuriyet Arşivi (BCA)

BCA, 030.18.1.2/268.48.18. (02.07.1971).

BCA, 030.18.1.2/273.77.5. (25.10.1971).

BCA, 030.18.1.2/269.52.3. (20.05.1975).

\section{Resmi Yayınlar}

Millet Meclisi Tutanak Dergisi (MMTD)

MMTD, D.3, C.14, T.2, B.114, s. 307. (16.06.1971).

MMTD, D.3, C.14, T.2, B.114, s. 308. (16.06.1971).

MMTD, D.3, C.14, T.2, B.114, s. 306. (16.06.1971).

MMTD, D.3, C.16, T.2, B.140, s. 264-265. (30.07.1971).

MMTD, D.3, C.22, T.3, B.49, s. 340. (25.02.1972).

MMTD, D.3, C.22, T.3, B.49, s. 303. (25.02.1972).

MMTD, D.3, C.22, T.3, B.49, s. 344-348. (25.02.1972).

MMTD, D.3, C.22, T.3, B.49, s. 328 (25.02.1972).

MMTD, D.3, C.22, T.3, B.49, s. 338 (25.02.1972).

MMTD, D.3, C.22, T.3, B.49, s. 327-328 (25.02.1972).

MMTD, D.3, C.22, T.3, B.49, s. 314-317 (25.02.1972).

Volume 12

Issue 5

October

MMTD, D.3, C.37, T.4, B.116, s. 670-678. (28.05.1973).

Cumhuriyet Senatosu Tutanak Dergisi (CSTD)

CSTD, C.1, T.11, B.3, s. 30. (11.11.1971).

CSTD, C.1, T.11, B.3, s. 29 (11.11.1971).

CSTD, C.1, T.11, B.3, s. 29-30. (11.11.1971).

CSTD, C.1, T.11, B.3, s. 28-32. (11.11.1971).

CSTD, C.2, T.11, B.28, s. 431. (04.02.1972).

CSTD, C.37, T.17, B.42, s. 184. (28.03.1978).

\section{Süreli Yayınlar}

Akşam

Bingöl

Dünya

Günaydın

Hürriyet

İkbal

Milliyet 
Son havadis

Tercüman

The Times

\section{Çeşitli Araştırma Eserleri ve Diğerleri}

ERİM, Nihat, 12 Mart Anıları, Yapı Kredi Yayınları, İstanbul 2007.

ÖZMEN, Bülent, “Türkiye Deprem Bölgeleri Haritalarının Tarihsel Gelişimi”, Türkiye Jeoloji Bülteni, C.55, S.1, Ocak 2012, s. 43-55.

ÖZMEN, Bülent-Süleyman Pampal, “Türkiye Deprem Bölgeleri Haritalarının Evrimi”, 4. Uluslararast Deprem Mühendisliği ve Sismoloji Konferansl, Anadolu Üniversitesi, Eskişehir 11-13 Ekim 2017, s. 194-204.

ÖZYILDIRAN, Güler, “1971 Burdur Depremi Sonrası İmar Çalışmaları”, Uluslararası Burdur Deprem ve Çevre Sempozyumu, Burdur, 7-9 Mayıs 2015, s. 311-321.

SEZER, Lütfi İlhan, "Karlıva (Bingöl) Yöresinin Depremselliği”, Ege Coğrafyası Dergisi, C.17, Sayı:1-2, 2008, s. 35-50.

ŞAHİN, Sakir, “Türkiye'de Afet Yönetimi ve 2023 Hedefleri”, Türk Deprem Araştırmaları Dergisi, C.1, S.2, 2019, s. 180-196.

TMMOB Makine Mühendisleri Odası, Türkiye’de Deprem Gerçeği ve TMMOB Makine Makine Mühendisleri Odasının Önerileri (Oda Raporu), Yayınevi ve yeri yok, 2010.

Türkiye’de Afet Yönetimi ve Doğal Kaynakl Afet Istatistikleri, Hazırlama Ekibi: Hakan Benli vd., AFAD Yayınları, Ankara 2018.

\section{Tezler}

KUŞOĞLU, İnci, Türkiye’de Orta Büyüklükteki Bazı Depremlerin Artçı Sarsıntı Süreç Analizi, (Kocaeli Üniversitesi Fen Bilimleri Enstitüsü, Yayımlanmamış, Yüksek Lisans Tezi), Kocaeli 2019.

TEMIZER, Mehmet, 2003 Bingöl Depremi Sonrası Bingöl İlinin Hasar Durumlarının Analizi, (Fırat Üniversitesi Fen Bilimleri Enstitüsü, Yayımlanmamış Yüksek Lisans Tezi), Elazığ 2013. 